ASSESSING READING TEXT IN ENGLISH TEXTBOOK FOR ELEVENTH GRADER PUBLISHED BY MINISTRY OF EDUCATION AND CULTURE

\title{
THESIS
}

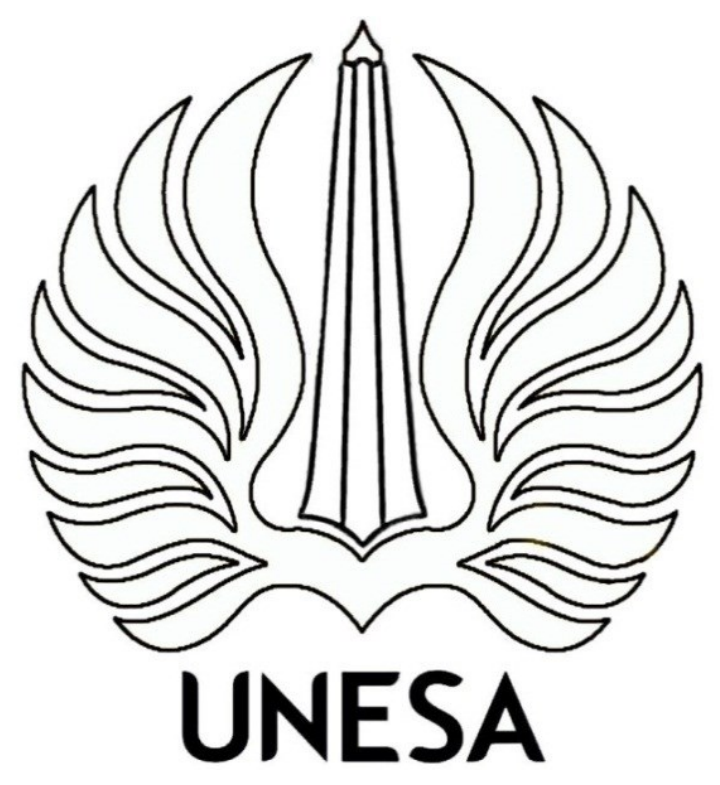

Rohib Adrianto Sangia

NIM 137835102

UNIVERSITAS NEGERI SURABAYA

PROGRAM PASCASARJANA

PROGRAM STUDI PENDIDIKAN BAHASA DAN SASTRA 2015 


\section{ASSESSING READING TEXT IN ENGLISH TEXTBOOK FOR ELEVENTH GRADER PUBLISHED BY MINISTRY OF EDUCATION AND CULTURE}

\section{THESIS}

Presented to Post Graduate Program of State University of Surabaya To Fulfill the Partial Requirements for Completing the Degree of Magister in Language and Literature Education Program

Advisors:

Prof. Abbas A. Badib, Ph.D

Suwono, Ph.D

Rohib Adrianto Sangia

NIM 137835102

UNIVERSITAS NEGERI SURABAYA

PROGRAM PASCASARJANA

PROGRAM STUDI PENDIDIKAN BAHASA DAN SASTRA

2015 


\section{APPROVAL SHEET}

This thesis entitled Assessing Reading Text in English Textbook for Eleventh Grader Published by Ministry of Education and Culture by Rohib Adrianto Sangia, NIM 137835102 has been examined in front of the Board of Examiners on August $25^{\text {th }}, 2015$.

Board of Examiners

Signatures

Occupation

Suharsono, M.Phil., Ph.D.

The Chairman

Prof. Abbas A. Badib, Ph.D.

The First Advisor

Suwono, Ph.D.

The Second Advisor

Ahmad Munir, M.Ed., Ph.D.

Member

Dr. Oikurema Purwati, M.Appl.

Member

Acknowledged by

Director of Post Graduate Program of UNESA

Prof. I Ketut Budayasa, Ph.D.

NIP. 195712041994021001 


\begin{abstract}
Sangia, Rohib Adrianto. 2015. Assessing Reading Text in English Textbook for Eleventh Grader Published by Ministry of Education and Culture. Thesis Advisors: Prof. Abbas A. Badib, M.A, M.A, Ph.D (I) and Suwono, Ph.D. (II)
\end{abstract}

Key words: Reading Text, Readability, Suitability, Miyazaki EFL Readability formula, McAlpine ${ }^{\circledR}$ EFLAW Formula

This research is aiming to answer the problems concerning the reading text material in English Textbook for Eleventh Grader published by Ministry of Education and Culture based on theory of good reading text (Nuttall, 2005). From three criteria that are proposed, this research is focusing to the readability and Suitability of reading text. Readability means as a term which refers to all the text features effecting how one reads and understands a book as a tool in matching the text and the reader. Suitability gives the opportunity to achieving learning goals with the appropriate text.

There are two methods used in assessing readability that are Miyazaki EFL Readability Formula and McAlpine ${ }^{\circledR}$ EFLAW Formula and both of them are quantitative methods. The readability formulas are used because they are created to determine text readability especially for EFL materials. In terms of assessing text suitability, the qualitative method is used by checking the target language covered by the reading text as the indicator of text suitability.

Based on text readability, it finds that overall reading texts Miyazaki EFL Readability score is 54.38 that can be interpreted as the reading text in the level of fairly difficult and suitable to eleventh grader. While using McAlpine ${ }^{\circledR}$ EFLAW Formula, the readability score achieves 18.89 with the meaning that the reading text in English textbook of eleventh grader is very easy to understand. In terms of suitability, it finds that, from 22 items of target language that is expected to be covered by the text, there are only 12 items which contain the target language which means text suitability is about $54.54 \%$ from overall text. 


\section{ACKNOWLEDGENT}

Alhamdulillahirobbil'alamin, praise to Allah Allah subhanahu wa ta'ala, the lord of universe, with its blessing and guidance so the agreement of this work can be finished. Sholawat and Salam always are given to our prophet Muhammad shallallahu 'alaihi wa sallam that brings people from the darkness to the lightness. I'd like to express my deepest gratitude to:

1. Director of Madrasah KEMENAG RI, Prof. Dr. Phil. M Nur Kholis Setiawan M. A. as the scholarship sponsor

2. Head of Language Art and Literature Study Program, Suharsono, M.Phil., Ph.D.

3. Prof. Abbas A. Badib, M.A, M.A, Ph.D. and Suwono, Ph.D. as thesis advisors

4. The examination committee of this thesis

5. Head of MA Negeri 1 Ambon, Drs. Sirajudin Mahubessy, M.M.Pd and Head of Administration, Miskia Sahadi, S.HI

6. Fellow friends in KEMENAG Class 2013 as well as teachers and staff in MA Negeri 1 Ambon

7. Family that always gives support especially my wife, Syifa Abdullah.

Finally, indebted feeling credits to all those who gave positive comments for the improvement of this thesis. 
TABLE OF CONTENT

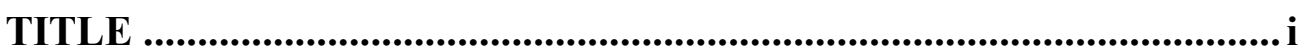

APPROVAL SHEET .............................................................................. ii

ABSTRACT

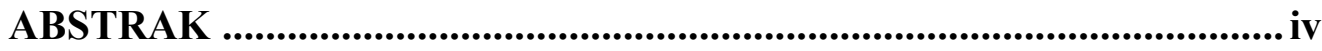

ACKNOWLEDGEMENT .....................................................................

TABLE OF CONTENT .................................................................. vi

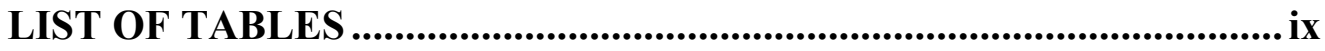

LIST OF FIGURES .................................................................................... $\mathrm{x}$

LIST OF APPENDICES .................................................................

I. INTRODUCTION ..................................................................... 1

1.1. Background of the Study ..................................................... 1

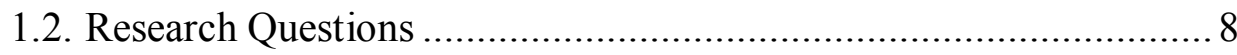

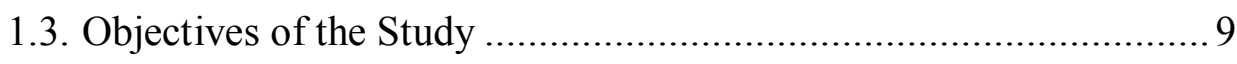

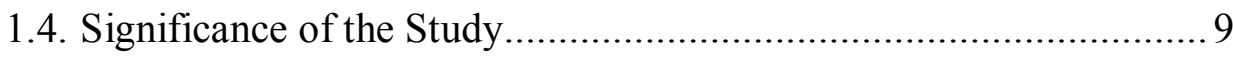

1.5. Scope and Limitation of the Study ............................................. 10

1.6. Definition of Key Terms ..................................................... 11

II. REVIEW OF RELATED LITERATURE ................................... 12

2.1 Theoretical Framework ......................................................... 12

2.1.1 Readability Concept ................................................ 12

2.1.2 The Readability of Reading Text.................................. 17

2.1.3 Readability for EFL Materials ........................................... 19

2.1.4 Suitability of the Reading Text......................................22 
2.2 National Curriculum 2013

2.2.1 Textbook in Curriculum 2013 ..........................................2 24

2.2.2 Competences for Eleventh Grader in Curriculum 2013 ........26

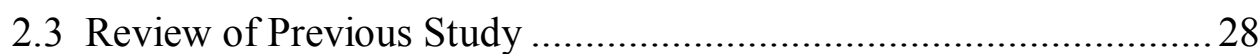

III. RESEARCH METHODOLOGY ...................................................31

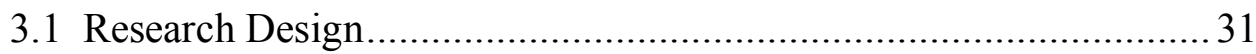

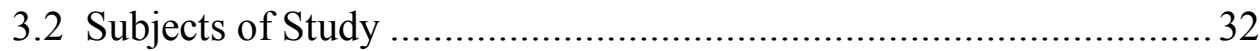

3.3 Data and Source of Data.......................................................... 33

3.4 Data Collection Techniques.......................................................... 34

3.4.1 Miyazaki EFL Readability Input ....................................... 34

3.4.2 McAlpine EFLAW® Input .......................................... 37

3.4.3 Assessing Suitability of the Text ......................................... 38

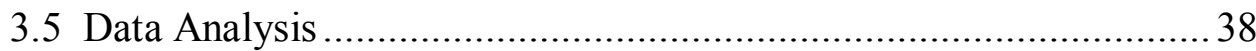

3.5.1 Miyazaki EFL Readability Formula ...................................39

3.5.2 McAlpine EFLAW® Formula........................................... 40

3.5.3 Target Language Checklist................................................. 41

3.6 The Trustworthiness of Data Analysis ...........................................41

IV. FINDINGS AND DISCUSSION ..................................................43

4.1 Readability of Reading Text ..................................................... 45

4.1.1 Miyazaki EFL Readability Score..................................... 45

4.1.2 Miyazaki EFL Readability Interpretation ......................... 50

4.1.3 McAlpine EFLAW® Score .........................................52

4.1.4 McAlpine EFLAW® Interpretation.................................56

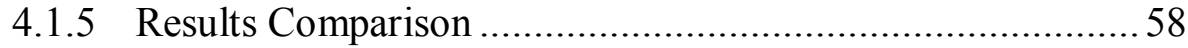

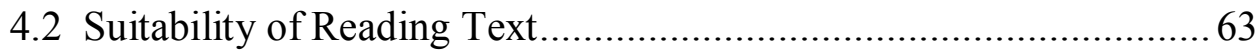


4.2.1 Analysis of Eleventh Grader English Curriculum ................6 64

4.2.2 Assessing Target Language in Reading Text ..................... 67

V. CONCLUSIONS AND SUGGESTION..........................................73

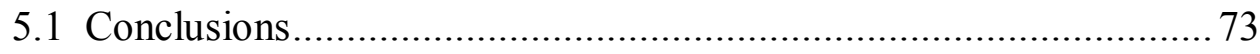

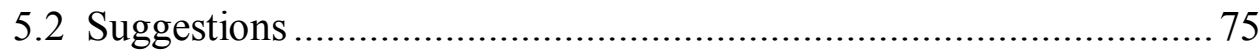

5.2.1 For the Publisher........................................................ 75

5.2.2 For the Teacher ............................................................. 76

5.2.3 For the Future Researcher ............................................. 76

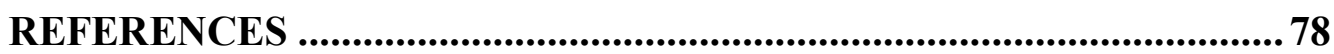

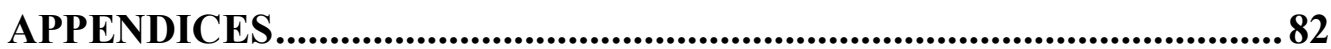




\section{LIST OF TABLES}

Table 3.1 Miyazaki Readability Score Interpretation .................................39

Table 3.2 McAlpine EFLAW® Score Interpretation ................................. 40

Table 3.3 Tentative Target Language Checklist Table ............................... 41

Table 4.1 Reading Text in English Textbook........................................... 43

Table 4.2 Issues of research question 1 .................................................. 45

Table 4.3 Miyazaki EFL Readability Description.....................................49

Table 4.4 Miyazaki EFL Readability Interpretation ...................................50

Table 4.5 McAlpine ${ }^{\circledR}$ EFLAW Score Description .................................... 55

Table 4.6 McAlpine ${ }^{\circledR}$ EFLAW Interpretation ........................................56

Table 4.7 Readability Score Comparison............................................5 58

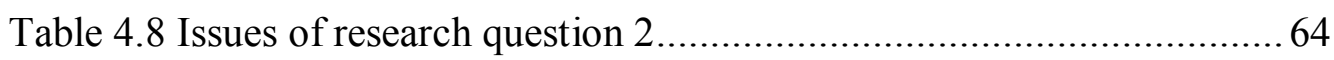

Table 4.9 Base competences and its target language ...................................65

Table 4.10 Relevancy of reading competence with text ........................... 72 


\section{LIST OF FIGURES}

Figure 3.1 Letter Counter Screenshots.................................................... 35

Figure 3.2 Microsoft ${ }^{\circledR}$ Words readability statistics report windows...............36

Figure 3.3 Microsoft ${ }^{\circledR}$ Windows scripts in counting mini-words.................. 37

Figure 3.4 Miyazaki EFL Readability Formula ........................................ 39

Figure 3.5 McAlpine EFLAW® Formula ............................................ 40

Figure 4.1 Miyazaki Readability Score Sequences ..................................51

Figure 4.2 McAlpine ${ }^{\circledR}$ EFLAW Score Sequences .......................................57

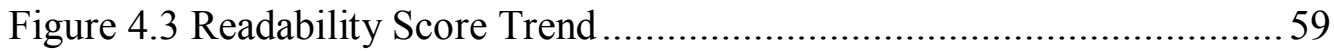

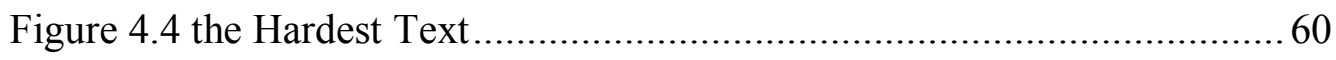

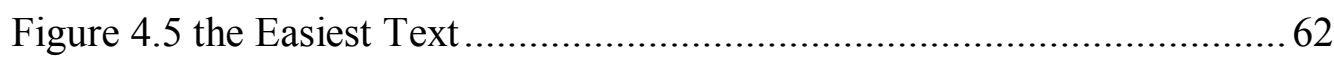




\section{CHAPTER I}

\section{INTRODUCTION}

This is a research report in investigating Reading Text in English Textbook for Eleventh Grader published by Ministry of Education and Culture in terms of Readability and Suitability.

This chapter provides the introduction that covers the background of the study, research questions, objectives of study, significance of the study, scope and limitation of the study, and definition of key terms.

\subsection{Background of the Study}

Teaching materials, for instance reading text, is an important part in the implementation of learning in school. Through teaching materials, for the teacher, it is easier to implement learning content and students are helped and easy to learn (Devetak \& Vogrinc, 2013: 3). Teaching materials can be written material or unwritten and used to help students in learning a certain subject. Teaching materials can be made in various shapes according to the needs and characteristics of teaching materials that are presented.

Textbooks are one of the essential teaching materials in teaching and learning activities. After all, many experts agree that they are the main resources in reading and endure a major instructional instrument in all grades except kindergarten (Bryce, 2013: 101). Besides that, it is useful for teachers who are not 
able or not ready to make their own teaching materials based on curriculum competency standard.

Richards (2001: 224-225) reports that textbook has several advantages in language learning. In advance, the textbook gives the organization of the course and the syllabus. Then, since it is organized, it is expected that it can standardize the language program in different classes. It also has the benefit in maintaining the quality. For the recent textbook, usually it is not only just the written material but it is accompanied by several supporting media, such as $\mathrm{CD}$, clips, cassette, etc. that can help the students input the language in various ways of learning experience. The textbook is assumed as efficient and effective teaching materials in language learning. In some places, there are teacher with low-qualification, can be helped in improving language teaching with the textbook. Finally, the textbook can improve the motivation both student and teacher in language learning by its design and production.

English Textbook for Eleventh Grader published by Ministry of Education and Culture is a compulsory textbooks published by the Education Ministry which is based on national curriculum 2013 to support education in Indonesia, in certain aspect, the availability of teaching materials. It is expected to avoid or to eliminate the gap between education in underdeveloped areas and the developed areas, in order to create learners who have mastery in science and technology. This textbooks is considered as the primary textbook based on Education Ministry Regulation in succeeding the implementation of National Curriculum (Kementerian Pendidikan Nasional, 2008). 
Based on the regulation, textbooks are required to be used in schools in the learning process, including giving students assignments and becoming reference of the exam questions. English Textbook is expected to actually have quality contents in accordance with the applicable curriculum both in terms of curriculum standards, content, and should be easily understood by both the teacher and the learners.

ELT textbook for instance "English Textbook for Eleventh Grader published by Ministry of Education and Culture", typically contains many elements presents mostly text which is most supposed as reading material, and followed listening instruction, writing, some conversation scripts, explanation text, and assessments' tools. Reading material used to teach reading like pronouncing words, comprehending the content of the text, getting vocabulary, and also understanding of grammar. By using the text, the students are expected to get information, knowledge of vocabulary and grammar. It is provided in some types which are called as genre. The types of genre are arranged well based on the competences that required in the curriculum.

In reading program, every student frequently finds problems in understanding a long text. Once they notice the text with long sentences, words with long syllables, and many paragraphs, the reading process become uninteresting and it can cause the decrease of the student motivation in learning. It gives impact in students' comprehension of the text. In order to select the appropriate reading material to the students, Nuttall (2005) suggest at least three criteria in selecting the reading text. They are suitability, exploitability, and 
readability (see H. D. Brown, 2001: 314). Suitability means that the content of the text makes learners feel interested, enjoyed, challenged, and appropriate in achieve learning target. Exploitability gives the opportunity to achieving learning goals with the text that can be deep exploration to instructional task, techniques, and also can be integrated into other part of language skills. Readability implicates lexical and structural difficulty which encourages them without upset.

It is similar with Bryce (2013: 102) who summarizes some problems of the textbook as set of reading material. These problems again can disturb the learning process of the students and teaching process of teachers. The first problem is the complaining of the text which is the difficulty of text so it creates mismatch situation between the text and the reader. The second is the text contains vocabulary such as technical vocabulary, abstract concepts, various registers, etc. that makes the reader need time to understand. The third is the superficial view of points of the text. Then, there is uninteresting and dry language which is used in the text. The fifth is the deficiency of user-friendly and organization style that makes the reader confuse. And the last is out-of-date and errors material in the text.

One of the factors determining the success of the students in the use of textbooks is determined by the quality of textbooks. In the measurement of the quality of textbooks should be considered important aspects such as the correctness of concepts and language with the content. Most of the teachers in the selection of teaching materials learning to read are always centered on the existing 
textbooks since textbook is a central instructional media use in the ELT classroom (Hutchinson \& Torres, 1994: 315).

The selection of reading materials is an important component in the process of learning to read in addition to the approach, methods, and strategies that played the teacher in the classroom. Students as learning center, for this reason, the teacher should be selective in choosing reading materials in an effort to understand the success of students' skills in reading the content.

Based on the problems referred earlier, the first problems about the difficulty of the text can be solved by assessing the text such as readability measurements. To determine the readability of a text or reading material can be measured by a variety of formulas (Schmidt \& Thomas, 2009: 73).

Readability is a term in the field of teaching reading which referring to text difficulty to find appropriate reading materials that students read (Mesmer, 2008: 7). Readability is often associated with the activities of whether the material is read by readers. From some views on legibility can be concluded that the legibility deciding factor is the difficulty of vocabulary as semantic variable and difficulty of sentence as syntactic variables.

Readability problems in teaching reading by the majority of English language teachers have not received important attention. Most English language teachers do not know the measuring instrument for determining the readability level of text. It means that most of local EFL teachers do not yet have the ability to measure the readability level reading materials used as teaching materials. As a result, it can be recognized that there is a gap between the reading materials and 
students' comprehension level. The gap becomes the factor of the reduction of the interest and motivation of students' reading.

In looking for a quick fix to match readers with reading material, Meade and Smith (1991: 154) list that readability formulas may be attracted for three reasons. Firstly, it is because their long position use in school settings. Secondly, their reputation is fit for systematic precision for organization text into suitable grade level groups. Thirdly, they perceived the notion of internal consistency within and between various formulas when determining reading levels.

Readability formulas are a formula that gives the figure as readability index (see 2.1.1). All readability formulas developed can predict whether a reading material is harder or easier to understand the reader when compared with other reading materials. The readability index can be used to predict the level of difficulty or ease-level reading material can be understood by the reader. The predictions can be used as a handle to determine the level of the reader. In addition, the prediction can be also used to determine or choose reading materials in accordance with a certain degree of reader comprehension (Burstein, 2009: 6). If so, then please be aware if any readability formula was carefully determining the level of legibility of the text so that the text is effectively used in the process of learning to read.

Manzo and Manzo (1990: 84) concern that generally, texts that have been written for Junior and Senior high school were converging to the content rather than for difficulty level. This comment has been inspiring of the textbook of junior and senior high school analysis in many places. As in Indonesia, many 
scholars have done many textbook in readability analysis such as, Listianingsih and Harjanto (2013); Rahmawati and Lestari (2014); Wijaya (2015). But what are they presented uncompromising results, because the formula that they used, most of them from the resources that should be done to the native rather that to the second language learners.

Those several classic formulas are not very accurate in predicting the difficulty EFL reading materials (Brown, 1998 :12). As a consequence, this study deploys two latest readability formulas that used specifically in measuring the EFL reading materials that are considered have better compatibility than the previous classic readability formulas. They are Miyazaki Readability Formula that developed by Greenfield (2003) and McAlpine EFLAW® Formula which is created by McAlpine (2005). Both formulas are counting the sentence length, but in the other variable, Miyazaki Readability Formula focuses on the length of words and McAlpine EFLAW® Formula adds the intensity of mini-words that is believed puzzled the EFL readers. Both formulas are expected to answer the problems of the reading text level and the appropriateness of the reader.

Suitability of content is arguably the most important after interest. A text that the teacher cannot exploit is no use for teaching even if the students enjoy reading it. The purpose of the reading lesson definitely gives positive effect when the students are improving in their EFL knowledge. But this ought to be considered an incidental bonus where it is not the purpose of the reading lesson. In a reading lesson teachers are not setting out to teach language. Alternatively, if teachers are focusing to teach language, they do not get in situation in giving a 
reading lesson. The focus of interest in the reading lesson is neither language nor content, but the two together. It is useful in making the students learn that language is used for conveying content.

It should be realized the important of analysis of reading text in English Textbook for Eleventh Grader published by Ministry of Education and Culture since it is considered as crucial subject because they have just released in the early 2014. After all, this research is going to study the element of the text as reading teaching material from English Textbook for Eleventh Grader published by Ministry of Education and Culture. This certain judgment for this study hopefully can raise some consideration for the establishment in using this book for the teachers and learners.

\subsection{Research Questions}

Based on the research background, the main research questions are aimed to answer the problems concerning the reading text material in English Textbook for Eleventh Grader published by Ministry of Education and Culture based on Nuttall's theory of good reading text. The research questions are formulated as the following:

1. How is readability of reading texts in English Textbook for Eleventh Grader published by Ministry of Education and Culture using Miyazaki EFL Readability Formula and McAlpine® EFLAW Formula? 
2. How is suitability of reading texts in English Textbook for Eleventh Grader published by Ministry of Education and Culture fulfilled the competences that required in the curriculum?

\subsection{Objectives of the Study}

In line with the research problems stated, the study intends to analyze English Textbook for Eleventh Grader published by Ministry of Education and Culture. Henceforth, the objectives of the study are framed as follows:

1. To investigate text difficulty of reading material in English Textbook for Eleventh Grader published by Ministry of Education and Culture based on Readability for EFL Material

2. To investigate whether reading material in English Textbook for Eleventh Grader published by Ministry of Education and Culture fulfills the requirement of good text in achieving the language goal based on reading competence in curriculum 2013

\subsection{Significance of the Study}

The findings of the research may give both theoretical functions and practical function. In terms of theoretical function, the findings may give contribution to support the theory about reading comprehension and reading text evaluation theories. This study also is expected to give numbers of significance information about reading text in English Textbook for Eleventh Grader published by Ministry of Education and Culture. After all, it can present enough theories to 
enrich the reader knowledge about reading comprehension and text evaluation and show how the theories are applied.

In terms of practical functions, the research result is expected to presents the application of readability in assessing or evaluating a reading text. From the result of readability, it is expected for the teachers to select the best reading material in order to maintain the students' motivation and student' performance in reading comprehension class. From the aspect of suitability, it gives confirmation of reading materials whether they facilitate the language goals according to basic competence in curriculum or not. After all, this study can give practical way in applying readability measurement by using Microsoft ${ }^{\circledR}$ Word features which can enrich teachers' knowledge and skills in taking the benefit of technology in terms of language learning generally and reading comprehension specifically.

\subsection{Scope and Limitation of the Study}

In order to make precise analysis, it is necessary to state the scope and limitation of the study. The scope of the research focuses on investigating the reading text in English Textbook for Eleventh Grader published by Ministry of Education and Culture.

The study is focusing on the evaluation of reading material in English Textbook for Eleventh Grader published by Ministry of Education and Culture. In aspect of investigating text difficulty, the method in measuring of the reading text

is using Miyazaki Formula and McAlpine EFLAW® formula. The readability formula measurement is going to use method by using the developed feature 
which has provided by word processing program such as Microsoft ${ }^{\circledR}$ Word feature.

\subsection{Definition of Key Terms}

Based on the statements of the research problems and to avoid misunderstanding and ambiguity in order to have clear same perception, orientation, and understanding, it is important to define several key terms that used in this study.

1. English Textbook for Eleventh Grader published by Ministry of Education and Culture is a specific book that contains manual of instruction of compulsory English language subject which is produced to facilitate the implantation of National Curriculum 2013

2. Readability is the ease of a text can be read and understood

3. Suitability is appropriateness of the text in in achieving learning objectives

4. Miyazaki EFL Readability Index and McAlpine EFLAW ${ }^{\circledR}$ Index are method in measuring text difficulties of EFL materials based on text surface.

5. Target language is the individual items of language (expressions, vocabularies, etc.) that the students want to study, or the teacher wants to teach. 


\section{CHAPTER II}

\section{REVIEW OF RELATED LITERATURE}

This chapter provides the related study that covers the topic of the study. It can give better knowledge and clear perception in order to treat the problems of the study. It contains two major parts that are theoretical framework and the previous studies.

\subsection{Theoretical Framework}

There are four major concepts that may give the contribution for this study that are readability concept, the readability of reading text, readability for EFL materials, and reading text suitability. It encloses many concepts from definition until the relationship to the current issues.

\subsubsection{Readability Concept}

The readability concept starts with the readability definition. Next on, it is presented the brief history of readability. Aspects in influencing the readability are explained and finally followed with the models of readability formulas.

Richards and Schmidt (2010: 482) define readability as the ease of a text can be read and understood. In addition, it is determined by on some aspects including the average length of sentences, the number of new words contained, and the grammatical complexity of the language used in a passage. 
In spite of everything, Mesmer (2008: 4) compiles the definition of readability as the term which refers to all the text features that effecting how one reads and understands a book. From the definitions, it is clear that readability scoping the relationship between the reader and the text, without considering the strategies or instruction which use in reading activities. The key purpose of readability existence is as a tool in matching the text and the reader (Davison, 1988: 40; DuBay, 2004: 10; Lapp, Flood, \& Farnan, 2004: 8; Mesmer, 2008: 7).

In the application of readability, most of the formula is focusing to the text. After measuring the text, the result can be used in judging the best reader to a certain text. Further in following section is explanation about history, the factor in readability, readabilities formula, and its application in EFL.

The study of readability has a long history with deep roots in the classical rhetoric of Plato and Aristotle and the ancient Hebrew scholars in analyzing vocabulary of their holly book. Later, the scholars were trying to enrich the understanding of language and text effectiveness, with the sign of the beginning of the history of readability in the 1920s (see Chall, 1988: 2).

DuBay (2004: 10) reports the beginning of the classic readability study was the model of studying literature from a statistical view point by English literature professor at the University of Nebraska, Lucius A. Sherman in 1893. From the experimenting of comparing the older prose writers with more popular modern writers, it was found that there was significance of progressive shortening of sentences over time. Furthermore, the result showed that how sentence-length averages shortened over time in the average is 20 words per sentence. Finally, the 
result made consequence that literature is a subject for statistical analysis, shorter sentences and concrete terms increase readability, spoken language is more efficient than written language, written language becomes more efficient over time by becoming more like spoken language (see DuBay, 2007: 2).

The similar text materials may be easier for one reader yet extremely tough to another. This fact showed that there are many factors in affecting the ease or hardship of a text to be digested. When considering readability, it is important to consider the complexity of the text.

That readability is difficult and not a simple, accurate measure is reflected in a statement confirmed by the Board of Directors of IRA as follow,

Many factors enter into determining the readability of materials, including the syntactic complexity of sentences, density of concepts, abstractness of ideas, text organization, coherence and sequence of ideas, page format, length of type line, length of paragraphs, intricacy of punctuation, and the use of illustrations and color. In addition, research has shown that student interest in the subject-matter plays a significant role in determining the readability of materials (see Olson \& Dishner, 2004: 8)

In the classic study of readability, most of the scholars were focusing their research in getting readability on the statistics which showed by the text. And then, as presented in the previous section, the paradigm of the text factors were change slowly went to the reader factors. From the brief history of readability, Mesmer (2008: 3 ) concludes that the most factors that should be considered a lot are both the text factors and the reader's factor.

Text factors can be found in the text and can be measured easily by observing and calculating the text statistics. Text factors can be broken into three parts as known as surface features, text ideas and concepts, and formatting. The 
first part is the matter of surfaces features. They are surface features are including the first surface known as words, then the second surface in sentence and the length.

Factors from the reader about their readability are divided into three major grounds. Mesmer (2008: 3) classifies them as abilities, motivation and knowledge. Abilities are concerns to reading-level of the students, their attention, and memory. Recognizing the reading levels of elementary students is principally important because their reading abilities develop and change massively across the elementary years. The capacity of things are different each other, so it needs treatments to meet them to the match text.

In beginning of $20^{\text {th }}$ century, scholars invented a method to use vocabulary difficulty and sentence length to forecast the difficulty level of a text. They implanted this method in readability formulas, which have proven their worth in over 80 years of application (DuBay, 2004). It is similar with Fry (2004: 42) argument that the two major input in readability formula are a semantic factor (meaning) which is presented by words and a syntactic factor (grammar) which is presented by sentences.

In the $1980 \mathrm{~s}$, there were 200 formulas and over a thousand researches issued on the readability formulas demonstrating to their strong theoretical and statistical validity. The several readability formulas are Flesch Reading Ease, Dale and Chall Original Formula, Gunning Fog Formula, and Smog Formula.

Flesch Reading Ease possibly most accountable for propagating the necessity for readability. He published a number of studies and approximately 20 
popular books about readability and English usage, as well worked as a readability consultant, lecturer, and teacher of writing. The formula drops the use of affixes and used only two variables, the number of syllables and the number of sentences for each 100-word sample. It predicts reading ease on a scale from 1 to 100 (see DuBay, 2004: 21).

A professor of education at Ohio State University, Edgar Dale, was a respected specialist on communications. He spent his whole life to develop the readability of books, pamphlets, and newsletters, etc. A formula he established with Jeanne Chall, the founder and director for 20 years of the Harvard Reading Laboratory. The original formula settled for adults and children above the $4^{\text {th }}$ grade (Zamanian \& Heydari, 2012: 45). They designed it to correct certain shortcomings in the Flesch Reading Ease formula. It uses a sentence-length variable plus a percentage of "hard words"-words not found on the Dale-Chall "long list" of 3,000 easy words, 80 percent of which are known to fourth-grade readers.

Robert Gunning was a graduate of Ohio State University. Gunning realized that much of the reading problem was a writing problem. In 1944, he became the first readability consulting firm. In the next several years, he tried and functioned with more than 60 large city daily newspapers and the popular magazines, facilitating writers and editors write to their spectators (DuBay, 2004: 24).

Harry McLaughlin publishes his SMOG formula in the belief that the word length and sentence length should be multiplied rather than added (see 
Zamanian \& Heydari, 2012: 46). The SMOG grade is a measure of readability that estimates the years of education needed to understand a piece of writing. SMOG is the acronym derived from Simple Measure of Gobbledygook. The SMOG grade yields a 0.985 correlation with a standard error of 1.5159 grades with the grades of readers who had $100 \%$ comprehension of test.

\subsubsection{The Readability of Reading Text}

To include a written text to a teaching program such as reading text in a textbook, a writer can decide to have the authentic text that would be linguistically 'difficult' for the students or simplify it so that it is linguistically 'easier' to students.

In terms of cultural knowledge, Steffensen, Joag-Dev, and Anderson (1979) explore marriage in North America between cultural familiar setting and unfamiliar setting. The result showed that the subjects were able to recall more, and more accurately to familiar setting than unfamiliar setting (see Alderson, 2000: 46). In line with it, Gebhardt (1987) states that much reading material, especially non-scientific reading is culturally biased and so can cause comprehension problems from students. The difference of culture between the writer and the reader causes problems of comprehension. In selecting reading material, or including reading text on a textbook, teachers or writers must consider the cultural aspect of the reading material to facilitate the students' understanding of the materials. 
Extensive exposure to linguistically comprehensible written text can enhance the process of language acquisition. Good reading texts also provide good models for writing, and provide opportunities to introduce new topics to stimulate discussion, and study language (i.e. vocabulary, grammar, idioms, etc.). Mostly or even every English textbooks consist of reading passages or texts. When selecting for reading, it should be consider the relevance of the content of matter and the level of difficulty of the texts.

Nuttall (2005) recommends that there are three points of view in selecting a text that are readability, suitability of content, and exploitability (see H. D. Brown, 2001: 314). Readability is that a text should be a right level of difficulty like lexical difficulty (words, phrase, idiomatic combination or phrasal verbs, vocabulary, etc.) and structural difficulty (grammatical forms, tenses, structural words, etc.). Suitability of content, in extensive reading material, comics, romances, and thrillers has all been used successfully by some teachers. While for intensive reading, studying short passages in context contributes many dimensions of study. Exploitability, for choosing a text should consider gaining the students' competence development as a reader. The considerations in this context are the clear objectives of reading activity and the purpose of the text usage.

Meanwhile Burns, Roe, and Smith (2011: 110) suggest consideration in selecting appropriate text for reading. The two areas that should be reflected in choosing a reading text are the relevance of the content matter; relevance means the text consider relevance of students' life experience, students' expressed needs, or learning program's goals and objectives, and the level of difficulty of 
the text; It depends on a combination of contextual and textual factors including the knowledge and experiences the reader brings to the text, the nature of reading task and the language of the text.

Consideration of text difficulty and how to simplify a text require some analysis of its language. An analysis of the language of the text also identifies important features to focus on in a lesson to encourage students' awareness of language. Such awareness is a vital aspect of students' ability to read critically. The ability to analyze the language of the text depends on linguistics knowledge.

\subsubsection{Readability for EFL Materials}

In recent times, there is a little concern about the appropriateness in applying readability formulas outside the native English contexts in which the formulas were originally developed. This demand has now initiated to be investigated by Brown (1998: 12) finds that several classic formulas were not very accurate in predicting EFL reading difficulty in this case Japanese university students. He assumed that there was in inaccurate validation of the classic readability formulas for EFL use.

The results, in somehow according to the view of Greenfield (2004), formula is unpractical to use, because it was requiring long-word and passagefrequency word counts in addition to parsing into function and non-function words. It left EFL teachers without an easy and reliable way to estimate a text's readability for their students. 
Another group of Japanese EFL readers was being completed. It revealed that the classic formulas discriminated text difficulty for those readers about as well as they do for native English readers. The study formed a formula scaled to those Japanese readers which is easy to use but offers only a minimal improvement in predictive correctness over the traditional formulas, which themselves verified to be fairly acceptable in the EFL as well as native speaker contexts (Greenfield, 2003: 42).

For such concerns, the research in formulating a new EFL readability formula was conducted. They are formula for Miyazaki Readability Index and McAlpine EFLAW® Index

The Miyazaki study in readability also involved Japanese university students and checked the Flesch Reading Ease and Flesch-Kincaid formulas along Dale-Chall, etc. Then, after researched, tested and validated, the study gave an output result that for convenience Greenfield (2004: 11) and his colleagues socalled the Miyazaki EFL Readability Index, turned out to be only marginally more accurate than the classic formulas. Fortunately, it is using the same text variables as the Flesch and Flesch-Kincaid formulas but adjusted to reflect the reading performance of our students.

The index informed scores on a 100-point scale analogous to the Flesch Reading Ease, representing the relation difficulty of texts without mention to performance criteria such as those implied in grade leveling. A score of 50 on the Miyazaki Index signified a text has average difficulty (Greenfield, 2003: 44). 
As a final point, in this framework, Greenfield (2003: 48) commented that the Miyazaki Index was such an important instrument for getting know about the students' performances in recognizing the text material that was given to them and the correctness of students' performances with the readings. After all, reading is a complex process, and it involves many linguistic, cultural, and individual learner factors in creating a proper assessments.

Foreign learners of English, like all others, are troubled by long sentences. One would expect that they would be equally confounded by long words. Interestingly, that need not be the case. The McAlpine EFLAW ${ }^{\circledR}$ Index is different from other readability indexes, because of the emphasis on short words. Usually, for native English readers, long words cause problems, not short words. They are agitated by mini-words clusters (McAlpine, 2005).

Miniwords are defined as common words that consists not more than three letters. Miniwords bunches in wordy commonplaces, colloquial expressions and phrasal verbs confuse foreign language readers. Furthermore, Miniwords are essential to English. But if a sentence is mostly mini-words, the sentence may confuse people who are learning English. Sentences starting with phrases like "It is" and "There are" can confuse international readers, especially if the sentence is long. In these cases, the words "it"" and "there" usually have no meaning.

Basically, the formula of McAlpine EFLAW® is constructing by several variables. Those variables are numbers of words, numbers of mini-words, and number of sentences. After taking the data and counting with the formula, the results are interpreted. 


\subsubsection{Suitability of the Reading Text}

Suitability, which Nuttall (2005: 30-31) defines as the facilitation of learning, is a key factor in selecting a reading material. Suitability refers to how the text can be used to develop the students' competence as readers. A text that cannot be exploited for teaching purposes has no use in the classroom. Just because it is in English does not mean that it can be useful. This indicates that the reading material helps the teacher to accomplish the objectives of the reading lesson or not. The content here was related to whether or not the texts provided were able to expand students' knowledge as well as to make students understand the target language.

With respect to suitability, the text content has to be developmentally, and linguistically, appropriate for improving the learners' comprehension strategies, and overcoming the vast amount of their reading deficiencies, because at the end, the basic learners deeply engaged in the meaning-making process of the selected text and therefore arrive successfully at thorough understanding of it.

\subsection{National Curriculum 2013}

Curriculum is a product of education policy that has to change all the time. In reality, it is not tended to change but rather to make improvement. The continuous improvement which is conducted has purposed to accommodate the material which is considered important and up-to-date. The improvements are conducted as implementation of one of curriculum development principle that a curriculum should be dynamic and flexible, so it can be change anytime according 
to the need (Sukmadinata, 2007: 109). In order to fulfill the need of the society, the curriculum changes should be done gradually and systematically.

The curriculum change is not only happened in Indonesia, but also in another modern country, since it is changed depend on the needs. The curriculum change is accepted in various countries normally and naturally. It is different with the negative view of ordinary people in Indonesia. This point of view should be straightened by looking at positive side that the change or improvement of curriculum cannot be stopped, and always be done because of the society needs (Katuuk, 2014: 13), knowledge, technology, art and culture.

There are two objective reason why the government intended to change to the national curriculum 2013 (see Katuuk, 2014: 14). First, prepare the Golden Generation Indonesia for a hundred years of independent Indonesia. Entering a hundred years of Indonesian independence (2045), the population of present students would have aged 35-44 years and 45-54 years. This group is a group of people that are in the reproductive age and is a prospective leaders. Because it is a strategic age group, they should be prepared as early as possible.

The second reason is the preparation of Indonesia's ability to deal with the problems associated with globalization: WTO, ASEAN Economic Community, APEC, CAFTA; environmental issues; advances in information technology; convergence of science and technology; knowledge-based economy; the rise of the creative and cultural industries; change of world economic power; quality, investment and transformation of the education sector. Demands of global 
developments produced a generation that has a need for competitive ability and the ability to solve difficult challenges in the future.

The learning process in the curriculum in 2013 is expected to create learning that allows educators to collaborate and share good experiences with other educators and with the learners. In addition, the expansion of the learning process is expected to take place in the learning community involvement. In order to be on the point of achieving the goals of learning the language, of course, we need a variety of formulas or approaches for the study. This is consistent with Gardner (2009: 107) submits that it should be able to have a set of basic teaching curriculum materials and a number of approaches, it also means that it is not bound by the requirement for a particular principle.

There are three approaches that compulsory to use. They are scientific approach, integrated thematic approach and thematic approach. From those approaches, the government claimed that the scientific approach is the new approach that is reliable to handle the entire subject. Thus, scientific approach is used to entire subjects especially in junior and senior high school (see Cahyani, 2013: 141).

\subsubsection{Textbooks in Curriculum 2013}

In curriculum 2013, textbook has significant role in teaching and learning process. By looking their importance, government makes the regulation about textbook procurement and spends a lot of funds in order to published and distribute the textbooks to the schools. The textbooks are used as a guidebook for 
teachers and students in learning activities in order to facilitate the students in mastering a specific competency. In addition, the textbook are published in two editions that are teacher's book and student's book.

The textbooks is also used to carry out a number of activities in the learning process, where content is designed and equipped with several examples of an activity sheet that the students were able to learn something more relevant to the life they experienced. They are intended to make students more effectively in follow any learning process through which to observe the activities, ask, try reason, discuss and improve the ability of the students in good communication among class member and the teachers.

Student's book is used as a guide learning activities to help students master certain competencies. This book is also used to carry out activities in the learning process (activities-based learning) in which it is designed and equipped to examples of activity sheets for students to learn something relevant to the life they experienced. Student's book directed to students more active in participating in the learning process through the activities of observing, ask, try, reason, discuss and improve the ability to communicate either between friends or with the teacher. Teachers can develop or enrich the material and other activities in accordance with the learning objectives that have been set.

Teacher's book is a guide for teachers in implementing the learning in the classroom. At least there are three major function of teacher's book, as instructions in using student's book, as reference of classroom activities, and as an explanation of the Learning Methods and Techniques Used in the Learning 
Process. As instructions in using student's book, teachers need to comprehend teacher's books. Teachers should find the following information such as firstly, the order of reference material on the subject developed graduates competency standards, core competence, and basic competency of each payload lessons, which are then combined into one specific theme. Secondly, network chapter of each theme chapter basic competencies and indicators of each payload lessons to be achieved. And thirdly, by sorting learning that developed from the sub-chapter with the aim that teachers can gradually organize the learning process based on the basic competencies that must be comprehended by students.

As reference of classroom activities, teacher's book presents several things. First, it describes the learning objectives to be achieved in any increments of learning from each sub-chapter. Then, it presents the media that can be used in carrying out the process of learning that teachers have prepared instructional media needed. Next, it defines the learning steps are done in organizing the learning process in order to assist teachers in teaching the execution plan, with systematic follow step-by-step learning. Later, it displays the techniques and instruments that can be used in any learning option which may have certain characteristics. Finally, it depicts the types of worksheets that correspond to existing learning increments in the Student Book.

\subsubsection{Competences for Eleventh Grader in Curriculum 2013}

It is believed that National Curriculum 2013 offers a learning shift from passive-students to active-student to research the knowledge from a variety of 
learning resources beyond the limits of teachers and schools. The role of English in the teaching model becomes very central needs by considering many learning resources are in English form than other languages combined. It is because of rapid growth of information and communication technology led to the association can no longer constrained by national boundaries.

Moreover, curriculum 2013 positioned the important role of the English language in conveying the idea of exceeding the limit and boundaries to engage ideas from outside which can be used for the benefit of national education. Thus competence for senior high school is expected have capability of being formulated as people of nation who give active contribution in global society

Similar with the reasons, the curriculum of English lessons for Eleventh Grader of highs cool is arranged to increase the language ability of the students. The representation of the material is using text-based approach for spoken and written material. Understanding of the types, principles and context of a text is emphasized so as to facilitate learners grasp the meaning of explicit and implicit in the text; also to present ideas in text form that is easy to understand the meaning of its content and lexical selection.

Curriculum 2013 emphasizes the importance of balancing the competence of the attitude, knowledge and skills. English proficiency is required to be formed through continuous learning: starting by improving the competence of knowledge about the types, principles and context of a text, followed by a skills competency to present a written and oral texts either planned or spontaneous with proper 
pronunciation and intonation, and lead to the formation of the attitude of politeness and respect for the beauty of the language.

\subsection{Review of Previous Studies}

The recent issues about the changing the national curriculum made some implication in textbooks as a part of curriculum. The new textbooks cannot be denied to have some analysis in the field of readability. This study is not spontaneous research that cannot be claimed never be done before. There are several studies that inspiring this study need to be done. In following, there is listed several local study about readability.

Listianingsih and Harjanto (2013) compose in their article about the investigation in the language readability levels of reading passages and the comprehension levels of exercises in Scaffolding for all grade in Junior High School. The authors use Flesch-Kincaid formula and Fry figure in assessing the language readability levels of reading passages in the textbooks. The research is focusing on the readability levels the base in judging the textbooks whether they are appropriate for the students or not. This article is useful predominantly in giving the information at glance about the readability concepts for this research. The article shows limitation in giving explanation and arguments that the formula that they use compatible for EFL students. The author points out the negative results by using the formula that need to have extended research. It is useful in reading the article since it is becomes the step stone in extending readability knowledge in assessing the readability for various readers. 
Almost same with the previous study, Rahmawati and Lestari (2014) are examining the readability levels books that used for tenth grade students. In comparing two books that used for tenth grade students, they are using Flesch Reading Ease formula and Fry Graph formula in solve the question about the textbooks differences in terms of readability. It is useful for this research since it is gives more information how to collect and analyze the data by using the formula. The boundaries rise when the information of EFL materials treatment does not appear. They found the differences about the readability index of the textbooks and suggest the adequate reader for the each book. There is need to find suitable formula in order to get accurate result for EFL Materials

The latest research from Wijaya (2015) is still focusing the readability examination for the textbook, Alexander's Practice and Progress. The author are using Flesch-Kincaid Grade Level, Coleman-Lieu Index, and SMOG in measuring the readability of the reading texts from the book and also functioning several online readability service on internet to gain the results. The research focuses on the results of readability analysis to have appropriateness readability grade level for the certain students. The limitation of the study is the unpractical of computational service that the researcher needs internet connection. The author sums up that readability of the text is not a major aspect to support students' comprehension. The research findings are useful in this research in order to gain better method and organization.

In terms of suitability of the reading text, Firdianti and Purwati (2013) conduct reading text analysis in junior high school English textbook. The study 
attempts to find out the relevance of the reading materials to the criteria of good reading material adapted from Depdiknas and BSNP by using documentary analysis in the form of descriptive qualitative research. The study is focusing on reading text in the textbook and their relation with the competences in curriculum. This study can give a blue print for design this research in terms of suitability. The limitation arises when it focuses on relevance that restricted by BNSP criterion. The authors find that the reading materials presented in the textbook are quite appropriate to be given to the students. This study is the basis of this research and useful as primary information of this research design and analysis.

Those are some of textbook researches that have conducted across the country and across of time. The research is focusing both on EFL readability and suitability in assessing the reading text. Somehow, in terms of readability, the use of computer software is tended to minimalize the errors in getting precision and accurateness. At least there are two offline software which are deploying, first is Microsoft ${ }^{\circledR}$ Word feature which used in getting text's statistics data as the input of Miyazaki EFL Readability Formula and McAlpine EFLAW® Visual Basic Script for Microsoft ${ }^{\circledR}$ Windows. 


\section{CHAPTER III}

\section{RESEARCH METHODOLOGY}

This chapter is going to give details about methodology in order to treat the problem in getting the objective of the research. It fills with research designs, subject of study, data and source of data, data collection technique, data analysis, and previous study.

\subsection{Research Design}

Related to the theories in text readability, it performs the theories from both Greenfield (2003) in using Miyazaki EFL Readability Index and McAlpine EFLAW® from McAlpine (2005). From the theories, they are the tools to know and to evaluate the suitability the reading material. From the findings, it is expected to show a certain patterns of the readability results in order to make the harmony in learning process.

In investigating the research problems, at least it is conducted with descriptive quantitative as the research method. Descriptive research provides an answer to the questions of how something happened and who was involved, but not why something happened or why someone was involved (Ary, Jacobs, \& Sorensen, 2010: 454).

This study is called quantitative since it has a tendency to what Creswell (2012: 13) characterizes a quantitative study such as collecting numeric data from the study subjects. Moreover, another sign is the procedure of the research is 
including the analyzing trends, comparing groups, or connecting variables using statistical analysis, and inferring results by comparing them with previous predictions and research.

Based on the concept of quantitative study by Ary et al. (2010: 26), this research is characterized as non-experimental quantitative research. The most convinced reason which is the different with experimental study is the variables in this study are authentic which means they don't have any modification, manipulation, controlled, or altered. It is simply using the variables from the subjects in describing their relation, correlation, with focusing demonstration a true cause-and-effect relationship.

In related to reading text suitability, the descriptive analysis is conducted. Johnson and Christensen (2008: 66) confirm that in a descriptive qualitative research, the data collected are in the form of words or pictures, documented books, and the other notes rather than numbers. The data would be analyzed descriptively without any statistical calculation. Therefore, this study was designed in descriptive qualitative research because the object of the study was a documented book., then it belongs to a documentary analysis since the researcher analyzed the data or texts which were derived from the textbook, then those were described in depth.

\subsection{Subjects of Study}

In directing the research in terms readability, the text statistic as the surface of the text are counted, meanwhile in terms of suitability, the content are 
examined whether they are fit and proper according material based on reading goals in base competences. The subjects are the reading texts which are that printed in English Textbook for Eleventh Grader published by Ministry of Education and Culture. A certain texts that are examined are the text that is really is used for reading topic according to syllabus.

Since a textbook contains many texts, there is data condensation in filtering the appropriate text based on the Core Competences from the National Curriculum 2013. Other things that should be concerned in the sum of the books are four exemplars. It is four because the textbooks are written for an academic term. The textbooks are published by Kementerian Pendidikan Nasional which has been revised to 2014 editions. The texts are examined by using Miyazaki EFL Readability Index and McAlpine EFLAWC Readability Index, after obtaining the input of the formula from the certain texts. The input is number of letters, number of words, number of sentences and number of mini-words. Those input are the variable for the formula that influences the readability results.

\subsection{Data and Source of Data}

It cannot be denied that study about readability is study about texts by observing a certain reading material. There are several things that are grabbed as the data in this study. By looking at Miyazaki EFL Readability formula, the data that are the formula input can be specified as numbers of letters, words, and sentences. The data for McAlpine EFLAW $®$ are the number of words, number of 
mini-words, and number of sentences. Those are kind that can be defined as the linguistics elements of texts, which can be obtained from observing the texts.

In conducting suitability evaluation, the data is taken from the content of the text. The data are target language such as expression, sentence, paragraph, or more, pieces of the text that indicates the material that compulsory based on the reading competence. Those data is expected reflecting material that demanded by the curriculum specially the substances of reading competence for eleventh grader of senior high school. Those data are examined later on by confirming with the reading competences to see hoe relevance and reliable the material in helping and facilitating the students' language knowledge to achieve the curriculum goals, especially in reading competence.

\subsection{Data Collection Techniques}

Data is the important things that become evidences and tools in describing and arguing the phenomena of the research site. In order to collect the data in this study uses two kinds of instruments. The first is by using statistical analysis that is by the Miyazaki EFL Readability input. The second is by using McAlpine EFLAW® Input. And finally, in assessing the suitability of the text is using observation technique.

\subsubsection{Miyazaki EFL Readability Input}

The first technique in collecting data is statistical analysis that is by the Miyazaki EFL Readability input. This kind of technique involves the counting 
letters, words, and sentences from the reading texts. With the purpose to gaining accuracy in using the software, it is necessary to type all the reading texts into form of Microsoft ${ }^{\circledR}$ Word data. When the texts are in form of word document, they can be converted and moved to the software analysis.

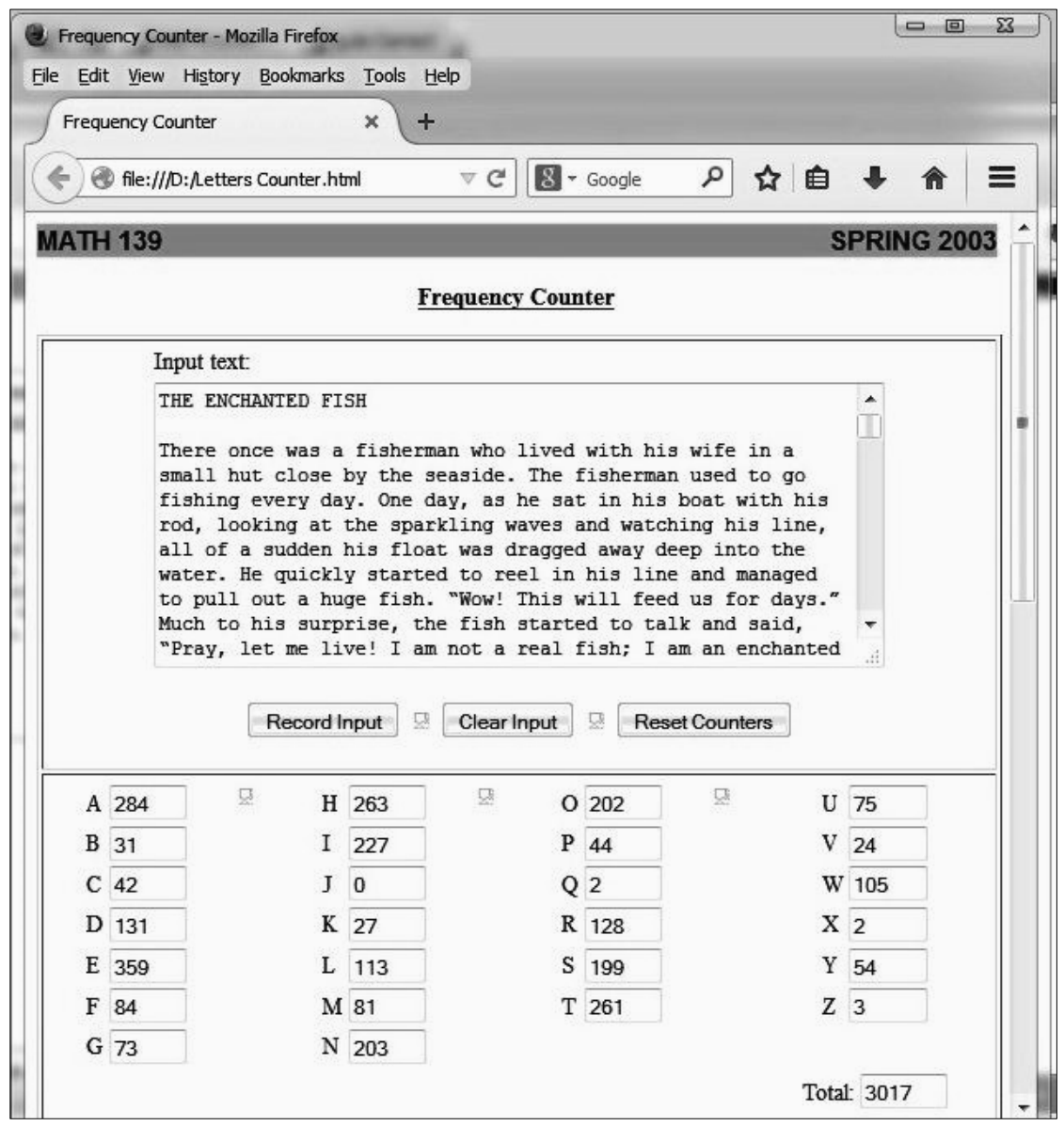

Figure 3.1

Letter Counter Screenshots.

1. Letters can be defined as written character in an alphabetic system of writing (McCarty, Watahomigie, Dien, Perez, \& Torres-Guzman, 2004: 65). It means that letter is part of characters, since characters represent all the written symbols. The problem arises when Microsoft ${ }^{\circledR}$ Word is only recognized characters not letters. In solving this problem, in counting letters, the 
researcher cannot rely on Microsoft ${ }^{\circledR}$ Word feature, but using offline webbased application which can count and give report about letters numbers and frequencies by pasting the texts on the input box (see Figure 3.1). The application is downloaded from Mount Holyoke College's website.

2. Linguistically, a word can defined as smallest elements of language which has meaning of its own, but in context of computational linguistics, Kuebler and Zinsmeister (2014: 45) define word as the series of characters which is located between spaces. It easily or be recognized, and Microsoft ${ }^{\circledR}$ Word has ability to count the words (see Figure 3.2).

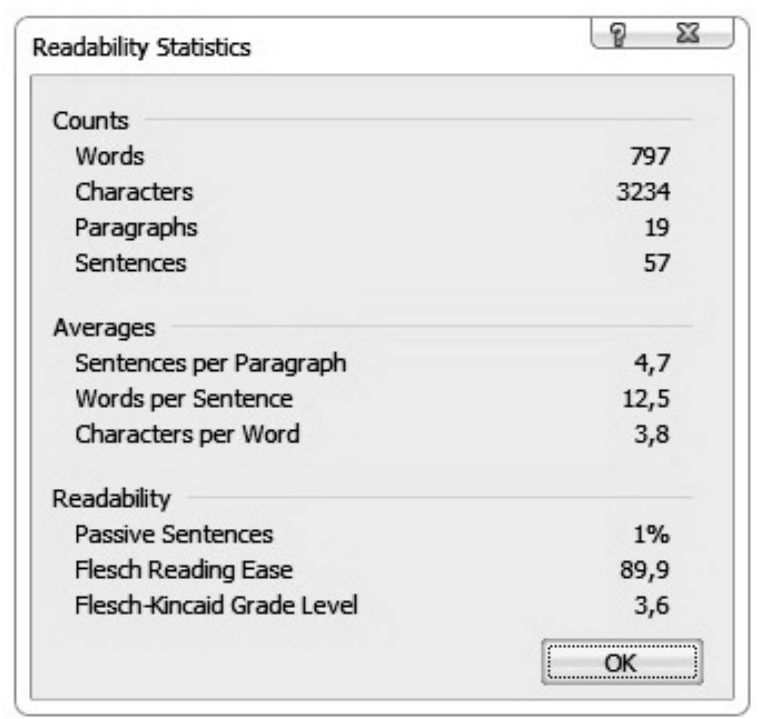

Figure 3.2

Microsoft ${ }^{\circledR}$ Words readability statistics report windows.

3. A sentence is a set of words that in principle tells a complete thought, typically a sentence contains a subject and predicate (Connelly, 2012: 617). In terms of computational linguistics, Halliday and Matthiessen (2004: 6) define a sentence as a group of words starting with a capital letter and ending in a full stop, such as a period, an exclamation mark, or a question mark as sign of a 
sentence boundaries. This parameters make Microsoft ${ }^{\circledR}$ Word can recognize and count sentences.

In order to have compromise and accuracy of the data, the counting is not only using manual method, but also it is used the word processor software such as Microsoft ${ }^{\circledR}$ word with its feature. Then, those elements are tabulated.

\subsubsection{McAlpine EFLAW® Input}

The first technique in collecting data is statistical analysis that is by the McAlpine EFLAW® input. This kind of technique involves the counting number of words, mini-words, and sentences from the reading texts. In order to have compromise and accuracy of the data, the counting is not only using manual method, but also it is used the Microsof ${ }^{\circledR}$ Windows scripts.

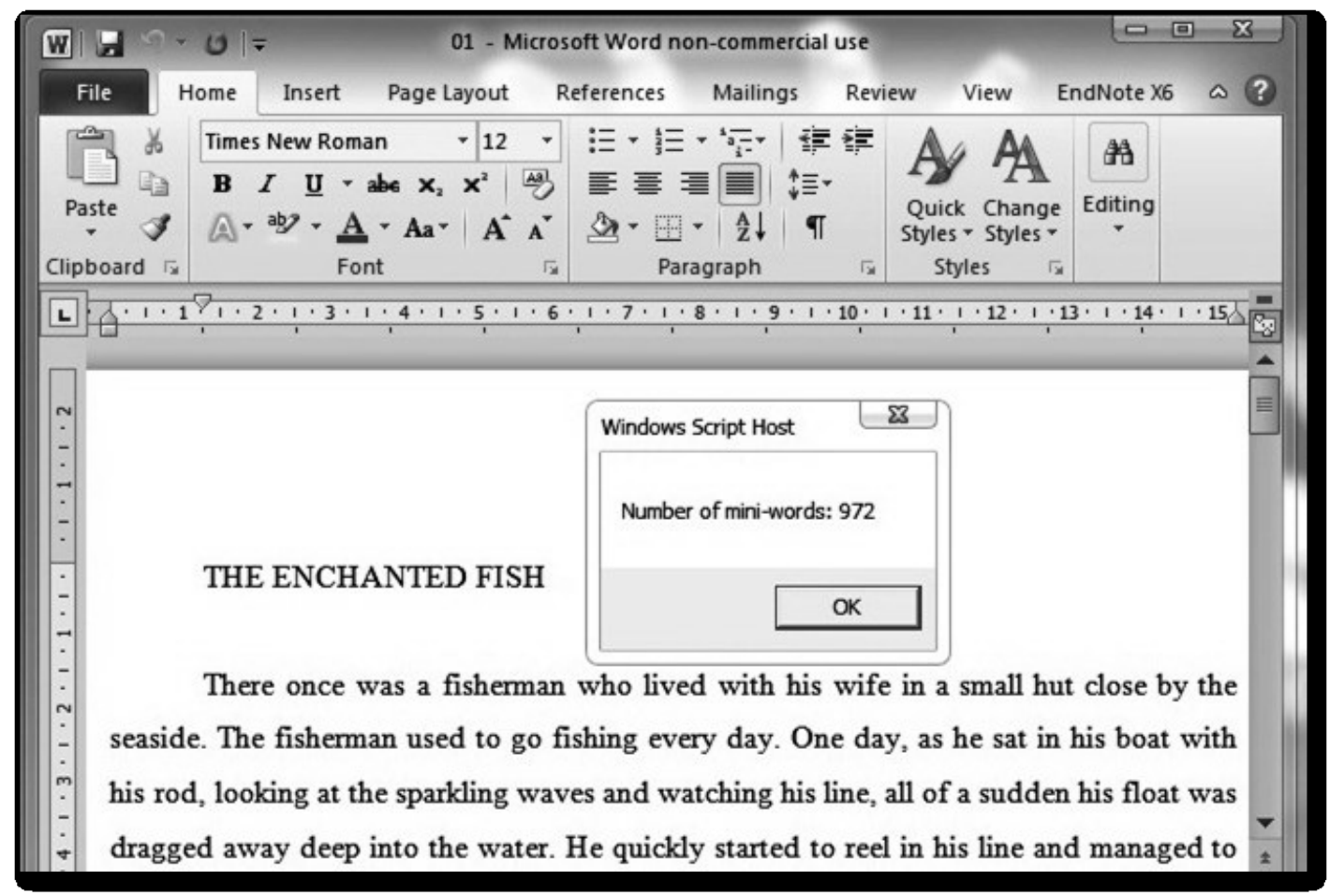

Figure 3.3

Microsoft ${ }^{\circledR}$ Windows scripts in counting mini-words. 
In counting words and sentences, the method can be seen in the previous section, where they can be computed by using Microsoft ${ }^{\circledR}$ Word feature. The figure describes how a Microsoft $\AA$ Windows script presents the result of number of mini-words from a reading text (see Figure 3.3). Later on, those elements are tabulated.

\subsubsection{Assessing Suitability of the Text}

In collecting the data, the researcher is using document observation technique. Not only reads over and over the reading materials in English Textbook for Eleventh Grader published by Ministry of Education and Culture, but also the researcher need to read over and over the learning goals of reading materials in Curriculum document particularly in the part of reading competence.

In selecting whether one is reading competences, it needs analysis of the curriculum document by observing and recognized them with viewing the syntax of competence sentence. Later on, the syntax that starts with certain operational or instruction words - i.e. menganalisa - and containing the object that specify as the text, it definitely can be predicted has close connection with reading competences.

\subsection{Data Analysis}

Since data has been collected from the source, the next step is conditioned with data analysis. Creswell (2012: 10) suggested that in data analysis, there are two process that should be done to the data. The first is taking the data apart in order to define individual responses and the second is putting them together to encapsulate it. 


\subsubsection{Miyazaki EFL Readability Formula}

In this study, the author used Miyazaki EFL Readability Formula, since the data which are taken are the inputs of this formula such as number of letters, numbers of words and numbers of sentences (see Figure 3.4).

$E F L$ Difficulty $=164.935-\left(18.792 \times \frac{\text { Letters }}{\text { Words }}\right)-\left(1.916 \times \frac{\text { Words }}{\text { Sentences }}\right)$

Figure 3.4

Miyazaki EFL Readability Formula (Greenfield, 2003: 44)

Analyzing the data is started with measuring the readability of each text based on the Miyazaki EFL Readability Formula. After that, it continues with describing and giving further explanation related to the readability. Later on, determining the index of each reading texts by comparing the results of the scores to the other criteria as shown in the readability index.

Table 3.1

Miyazaki Readability Score Interpretation

\begin{tabular}{|c|c|c|}
\hline \hline Reading Ease Score & Style Description & Estimated Reading Grade \\
\hline \hline 0 to 30 & Very Difficult & University graduate \\
\hline 30 to 50 & Difficult & Post-school/College \\
\hline 50 to 60 & Fairly Difficult & $10^{\text {th }}$ to $12^{\text {th }}$ grade \\
\hline 60 to 70 & Standard & $8^{\text {th }}$ and $9^{\text {th }}$ grade \\
\hline 70 to 80 & Fairly Easy & $7^{\text {th }}$ grade \\
\hline 80 to 90 & Easy & $6^{\text {th }}$ grade \\
\hline 90 to 100 & Very Easy & $5^{\text {th }}$ grade \\
\hline
\end{tabular}

All data of Miyazaki EFL Readability are gathered and be analyzed. After getting the results from the formula, there is the explanation about the correlation between texts and the trend of the texts. It shows the comments around the results based on the description of the index (see Table 3.1). 


\subsubsection{McAlpine EFLAW® Index}

McAlpine EFLAW® Formula is used, since the data which are taken are the inputs of this formula such as number of words, numbers of mini-words and numbers of sentences (see Figure 3.5).

McAlpine EFLAW@ Score $=\frac{(\text { Number of Words }+ \text { Number of Miniwords })}{\text { Number of Sentences }}$

Figure 3.5

McAlpine EFLAW® Formula

Analyzing the data is started with measuring the readability of each text based on the McAlpine EFLAW® Formula. After that, it continues with describing and giving further explanation related to the readability. Later on, determining the index of each reading texts by comparing the results of the scores to the other criteria as shown in the readability index.

Table 3.2

McAlpine EFLAW® Score Interpretation

\begin{tabular}{|c|c|}
\hline \hline Score & Description \\
\hline \hline 1 to 20 & Very Easy to Understand \\
\hline 21 to 25 & Quite Easy to Understand \\
\hline 26 to 29 & A Little Difficult \\
\hline $30+$ & Very Confusing \\
\hline
\end{tabular}

All data of Miyazaki EFL Readability are gathered and be analyzed. After getting the scores from the formula, there is the explanation about the correlation between texts and the trend of the texts. It shows the comments around the scores based on the description of the index (see Table 3.2). 


\subsubsection{Target Language Checklist}

Basically, suitability concerns to the content of the reading text. It means that more the target language based on the reading competence in the text, the increasing validity of the reading material to the curriculum demands. In order to capture the data, and analyze them, it is using some kind checklist that contains both text columns and target language columns (see Table 3.3).

Table 3.3

Tentative Target Language Checklist Table

\begin{tabular}{|c|l|c|c|c|c|c|c|c|}
\hline \hline \multirow{2}{*}{ No } & \multirow{2}{*}{ Target Language } & \multicolumn{7}{|c|}{ Text Number } \\
\cline { 3 - 9 } & & $\mathbf{1}$ & $\mathbf{2}$ & $\mathbf{3}$ & $\mathbf{4}$ & $\mathbf{5}$ & $\mathbf{6}$ & $\ldots$ \\
\hline \hline 1. & Expressing Suggest & $\sqrt{ }$ & & & & & & \\
\hline 2. & Expressing Offer & & & & & & & \\
\hline 3. & Expressing Opinion & & & & & & & \\
\hline 4. & $\ldots$ & & & & & & & \\
\hline
\end{tabular}

\subsection{The Trustworthiness of Data Analysis}

The trustworthiness of the data analysis results is necessary to be done. The purpose of having trustworthiness is to confirm and verify whether the result of analysis is accurate and true or not. Hence, the researcher prevented the accuracy of the result based on the researcher's opinion, biases and prejudices. To support in getting the trustworthiness of the data that have been analyzed, the researcher used triangulation techniques.

Creswell (2012: 629) defines triangulation as the process of verifying evidence from different point of view such as subjects, types of data, or methodology by giving descriptions and also in scope of qualitative research. Mention by Ary et al. (2010: 499-500), there are at least five types of triangulation which are data triangulation, methods triangulation, investigator triangulation, 
theory triangulation, and finally interdisciplinary triangulation. In relation with assessing suitability of the text that basically using qualitative method, the researcher is going to use investigator triangulation. Investigator triangulation involves third-person researcher that having capable and competence in conducting such kind of this research independently. The third-person researcher in Magfur, M.Pd, a teacher as well as lecture in Education field especially English Language and Art with recent experience as the editor of English Teaching Guidance Book in implementation of Curriculum 2013. 


\section{CHAPTER IV}

\section{FINDINGS AND DISCUSSION}

The first section of this chapter is presenting the finding and discussion about the reading text in terms of readability that would be the answer of the first research question. Based on readability, the variable that has been taken is being recapitulated and displayed. The second part is presenting the findings of discussion of the text suitability as the answer of the second research question. But before going there, it is necessary to depict the general information of the textbook

Table 4.1

Reading Text in English Textbook Volume I and II

\begin{tabular}{|c|c|c|c|c|c|}
\hline No & Code & Title & Volume & Chapter & Pages \\
\hline 1. & Text 01 & The Enchanted Fish & $\mathrm{I}$ & 1 & $3-5$ \\
\hline 2. & Text 02 & $\begin{array}{l}\text { Bullying: A cancer that } \\
\text { must be eradicated }\end{array}$ & I & 2 & $28-30$ \\
\hline 3. & Text 03 & $\begin{array}{l}\text { President Sukarno of } \\
\text { Indonesia: Speech at the } \\
\text { Opening of the Bandung } \\
\text { Conference, April 18, } 1955\end{array}$ & I & 3 & $50-51$ \\
\hline 4. & Text 04 & Vanity and Pride & $\mathrm{I}$ & 4 & $70-74$ \\
\hline 5. & Text 05 & Letter to GOD & $\mathrm{I}$ & 5 & $92-94$ \\
\hline 6. & Text 06 & Story of Technical Writing & II & 6 & $3-5$ \\
\hline 7. & Text 07 & $\begin{array}{l}\text { Earthquake, The Most } \\
\text { Deadly Natural Hazards }\end{array}$ & II & 7 & $28-30$ \\
\hline 8. & Text 08 & The Last Leaf & II & 8 & $47-49$ \\
\hline 9. & Text 09 & $\begin{array}{l}\text { Life and Times of Ki Hajar } \\
\text { Dewantara (Raden Mas } \\
\text { Suwardi Suryaningrat) }\end{array}$ & II & 9 & $65-66$ \\
\hline 10. & Text 10 & $\begin{array}{l}\text { "Stand By Me" by Ben E } \\
\text { King }\end{array}$ & II & 10 & 82 \\
\hline 11. & Text 11 & $\begin{array}{l}\text { Global Warming, Is it an } \\
\text { end to our world? }\end{array}$ & II & 11 & $108-109$ \\
\hline
\end{tabular}


Table 4.1 describes the map of the reading text in the textbook. It is important in coding the text name into text 01 to text 11 . Those texts are arranged by giving their position in the book volumes, chapters, and pages. This step is made with the intention to make easier the researcher as well as the reader of this paper in checking and confirming the finding in the analysis. All of the text is distributed in each chapters and occupied the face of the chapter reflected that those texts play important roles in learning process. Furthermore, it can be assumed that the reading texts in the textbook initiated the reading activity to help the students, not only focused in reading ability but also expected to stimulate another language skill such as listening, speaking as well as writing.

English textbook for eleventh grader is published by Kementerian Pendidikan dan Kebudayaan as the effort of the implementation of National Curriculum 2013. The textbook is printed with colorful appearance and published in two volumes (see Table 4.1). The volume is represented the terms or semester of an academic year.

Both of two condition above which are colorful appearance and published in two volumes give strength and weakness of the textbook. Colorful appearance is intended to increase students' motivation in studying English. It is expected to give clear descriptions about the target languages that they learned in graphical ways. The textbook look and the volumes make the cost of the book bigger. For the good side, publishing textbook in two volumes gives the installment to the students so they can save their money and also reduce their schoolbag weight. 


\subsection{Readability of Reading Text}

Based on the first research question, this research is studying the readability of reading text in English textbook for eleventh grader published by Ministry of Education and Culture basically in two formulas that are Miyazaki EFL Readability Formula and McAlpine ${ }^{\circledR}$ EFLAW Formula.

Table 4.2

Issues of research question 1

\begin{tabular}{ll}
\hline \multicolumn{1}{c}{ Research Question } & \multicolumn{1}{c}{ Issues } \\
\hline How is readability of reading texts in & 1. Miyazaki EFL Readability Score \\
English Textbook for Eleventh Grader & 2. Interpretation with Miyazaki EFL \\
published by Ministry of Education & Readability Score \\
and Culture using Miyazaki EFL & 3. McAlpine EFLAW Score \\
Readability Formula and McAlpine $\circledR$ & 4. Interpretation with McAlpine ${ }^{\circledR}$ \\
EFLAW Formula & EFLAW Score \\
& 5. Results Comparison \\
\hline
\end{tabular}

\subsubsection{Miyazaki EFL Readability Score}

In collecting data, the research extracts the reading texts from the English textbook for eleventh grader and focuses on the reading texts to counting the surface of the text which are number of letters, number of words, and number of sentences. Those text surface elements (number of letters, number of words, and number of sentences) are the input that is formulated to get the readability score based on Miyazaki Readability Formula.

After examining Text 01, it is found 57 sentences, 797 words, and 3017 letters. The calculation of average sentence length is 13.98 and average word length is 3.79 . From the input that has been calculate, the readability score of Text 01 based on Miyazaki readability formula is 67.01 . This score gives the information that Text 01 is a standard difficulty. 
A text 02 investigation gives certain information about numbers of text surface elements which are 45 sentences, 775 words, and 3670 letters. From those results, it is deliberated that Text 02 has 17.22 of average sentence length and 4.74 for average word length. Then, the application Miyazaki Readability formula for those inputs outcomes the score which is 42.95 . The score 42.95 is presenting that the text is difficult to be read. Text 02 result is lower than the previous text. The indicators can be seen to the average word length and the average sentence length. The lower results makes Text 02 is harder that Text 01 .

In Text 03, the statistic gives results which are 33 sentences, 499 words, and 2255 letters. From those number, the average of sentence length is projected as 15.12 and the average word length is 4.52 . The input is calculated with Miyazaki readability formula and gaining score 51.04. The score give interpretation that Text 03 is fairly difficult. The higher marks of the average word length and the average sentence length of Text 03 than Text 02 , makes the readability score of Text 03 increased. This condition put text 03 is easier to be read than text 02 .

The average sentence length of Text 04 is 8.51 and followed with the average of word length is 4.50 . Those numbers are result of the surface of text numbers which are consisted of 114 sentences, 970 words, and 4364 letters. After that, the input is calculated to get the results which is 64.09 . From the score, it can be estimated that Text 04 is considered has standard difficulty. Text 04 is assumed easier than the previous text by seeing it readability score. The average 
sentence length and the average word length makes it gets the higher score than Text 03.

Next in the Text 05 , it is found that the Text is consisted of 90 sentences, 1142 words, and 4705 letters. From the numbers it shows that the average of sentence length is 12.69 and the average of word length is 4.12 . All the input is formulated and then give result that the Text has readability score is 63.20 which is considered as standard text. After the escalation of the readability score chronologically in the last three texts, Text 05 shows the decreasing readability score. The variables that are the average sentences and word length give contribution makes Text 05 is harder than the previous text but it is easier if it is relating to Text 03 .

The beginning text that can be found in second volume of English Textbook for eleventh grader published by Kementerian Pendidikan Nasional, Text 06 is constructed from 47 sentences, 847 words, and 4495 letters. They make the average sentence length as 18.02 and the number of average word length as 5.31. The score that resulted from those numbers is 30.68 . This results makes Text 06 has difficult readability. It is harder to be read than Text 07 that will be deliberated next.

Text 07 consists with 35 sentences, 560 words, and 2800 letters. From those data makes it makes the result of sentence average length become 16.00 and average word length turn into 5.00. The score from the input that are number of letters, words, and sentence, caused the score that gained by Text 07 is 40.32 . From this score, Text 07 can be considered hard or difficult to be read. Even 
though it is difficult to be read based on the index, it can be assumed that Text 07 is easier than the previous text. The different can be looked at the average sentence length and the average word length.

Following passage, Text 08 is inclosing with 95 sentences, 1028 words, and 4300 letters. It means that the average sentence length of Text 08 is 10.82 . Later on the average of word length is estimated as 4.18 . The readability score that is gained from this passage is 65.60 . This score which is conveyed based on Miyazaki EFL Readability formula defines that the text is in standard range of readability level. It is the continuous escalation of readability score from the two previous texts. It means that the texts move to be easier.

The average of sentence length in Text 09 is 19.53 and it average word length is 5.16. They come from the number of letters that are 3427 , the number of words which are 664, and 34 sentences. The readability score of this passage is 30.53 which is describe the level of text difficulty in difficult place. It shows that the readability score in this text falls after the triple growth.

The investigation of Text 10 raises the result of formula input which is 28 sentences, 165 words, and 557 letters. The average sentence length from this text is 5.89 and followed with average word length is 3.38. From the calculation of the input by applying the readability formula, the readability score of the text is 90.21. The score gives meaning that Text 10 is very easy to understand, which is contradictive to the previous text. Contradictive means that Text 09 gains the lowest readability score from all of the text, and Text 10 is in the highest place of 
readability score. Therefore, both text can be highlight as the easiest and the hardest texts that to be read by the students.

Text 11 as the last text that is explored in order to it's the readability. It gains readability score as much as 37.95 . It comes from average sentence length which is 19.35 and average word length is 4.78 . Text 11 is created by using 3148 letters, 658 words, and 34 sentences.

Table 4.3

Miyazaki EFL Readability Description

\begin{tabular}{|c|c|c|c|c|c|}
\hline \multirow{2}{*}{ No. } & \multirow{2}{*}{$\begin{array}{l}\text { Text } \\
\text { Code }\end{array}$} & \multicolumn{3}{|c|}{ Miyazaki EFL Readability Input } & \multirow{2}{*}{$\begin{array}{c}\text { Miyazaki EFL } \\
\text { Readability Scores }\end{array}$} \\
\hline & & $\begin{array}{c}\text { Number of } \\
\text { Letters }\end{array}$ & $\begin{array}{c}\text { Number of } \\
\text { Words }\end{array}$ & $\begin{array}{l}\text { Number of } \\
\text { Sentences }\end{array}$ & \\
\hline 1. & Text 01 & 3017 & 797 & 57 & 67.01 \\
\hline 2. & Text 02 & 3670 & 775 & 45 & 42.95 \\
\hline 3. & Text 03 & 2255 & 499 & 33 & 51.04 \\
\hline 4. & Text 04 & 4364 & 970 & 114 & 64.09 \\
\hline 5. & Text 05 & 4705 & 1142 & 90 & 63.20 \\
\hline 6. & Text 06 & 4495 & 847 & 47 & 30.68 \\
\hline 7. & Text 07 & 2800 & 560 & 35 & 40.32 \\
\hline 8. & Text 08 & 4300 & 1028 & 95 & 65.60 \\
\hline 9. & Text 09 & 3427 & 664 & 34 & 30.53 \\
\hline 10. & Text 10 & 557 & 165 & 28 & 90.21 \\
\hline 11. & Text 11 & 3148 & 658 & 34 & 37.95 \\
\hline \multicolumn{2}{|c|}{ Overall } & 36738 & 8105 & 612 & 54.38 \\
\hline
\end{tabular}

Based on the texts result (see Table 4.3), they can be summarized as the longest text is Text 5 because it has the most numbers of letters and words. And the shortest text is hold by Text 10 since it has the fewest letters and words numbers. Then, for the all text readability score based on Miyazaki Readability formula, Text 10 is considered is the easiest text from the textbook with score 90.21 and Text 09 is projected as the hardest text to be read with readability score 30.53 . 
In the first volume of the textbook, it finds that the overall readability score from text 01 to Text 05 is 60.38 . It means that the first volume is easier to be read by the eleventh grader students. In the second volume, the finding shows that the accumulation of the readability variables from Text 06 to Text 11, makes the second volume overall readability score 47.68 . This is far from the previous volume results. It makes the second volume is consistently harder than the first volume. After gaining all readability score from Text 01 to Text 11 , finally the readability score of all reading text from the textbook based on Miyazaki Readability formula is 54.38 .

\subsubsection{Miyazaki EFL Readability Interpretation}

Table 4.4

Miyazaki EFL Readability Interpretation

\begin{tabular}{|c|c|c|c|c|c|}
\hline No & $\begin{array}{l}\text { Text } \\
\text { Code }\end{array}$ & $\begin{array}{c}\text { Readability } \\
\text { Score }\end{array}$ & Style Description & $\begin{array}{c}\text { Estimated } \\
\text { Reading } \\
\text { Grade }\end{array}$ & Quality \\
\hline 1. & Text 01 & 67.01 & Standard & $8^{\text {th }}$ and $9^{\text {th }}$ & Easier \\
\hline 2. & Text 02 & 42.95 & Difficult & College & Harder \\
\hline 3. & Text 03 & 51.04 & Fairly Difficult & $10^{\text {th }}$ to $12^{\text {th }}$ & Match \\
\hline 4. & Text 04 & 64.09 & Standard & $8^{\text {th }}$ and $9^{\text {th }}$ & Easier \\
\hline 5. & Text 05 & 63.20 & Standard & $8^{\text {th }}$ and $9^{\text {th }}$ & Easier \\
\hline 6. & Text 06 & 30.68 & Difficult & College & Harder \\
\hline 7. & Text 07 & 40.32 & Difficult & College & Harder \\
\hline 8. & Text 08 & 65.60 & Standard & $8^{\text {th }}$ and $9^{\text {th }}$ & Easier \\
\hline 9. & Text 09 & 30.53 & Difficult & College & Harder \\
\hline 10. & Text 10 & 90.21 & Very Easy & $5^{\text {th }}$ grade & Easier \\
\hline 11. & Text 11 & 37.95 & Difficult & College & Harder \\
\hline \multicolumn{2}{|c|}{ Overall } & 54.38 & Fairly Difficult & $10^{\text {th }}$ to $12^{\text {th }}$ & Match \\
\hline
\end{tabular}

The quality of the text is described in three ways (see Table 4.4). The first is harder when the readability score is exceed the recommended Grade reading for eleventh grader based on Greenfield (2003: 44). The second is when the 
readability score is less than the recommended readability score range. And the third place which is match, when the score which is gained from the text exactly taking place between 50 and 60 that it is the appropriate readability score range for eleventh graders reading text.

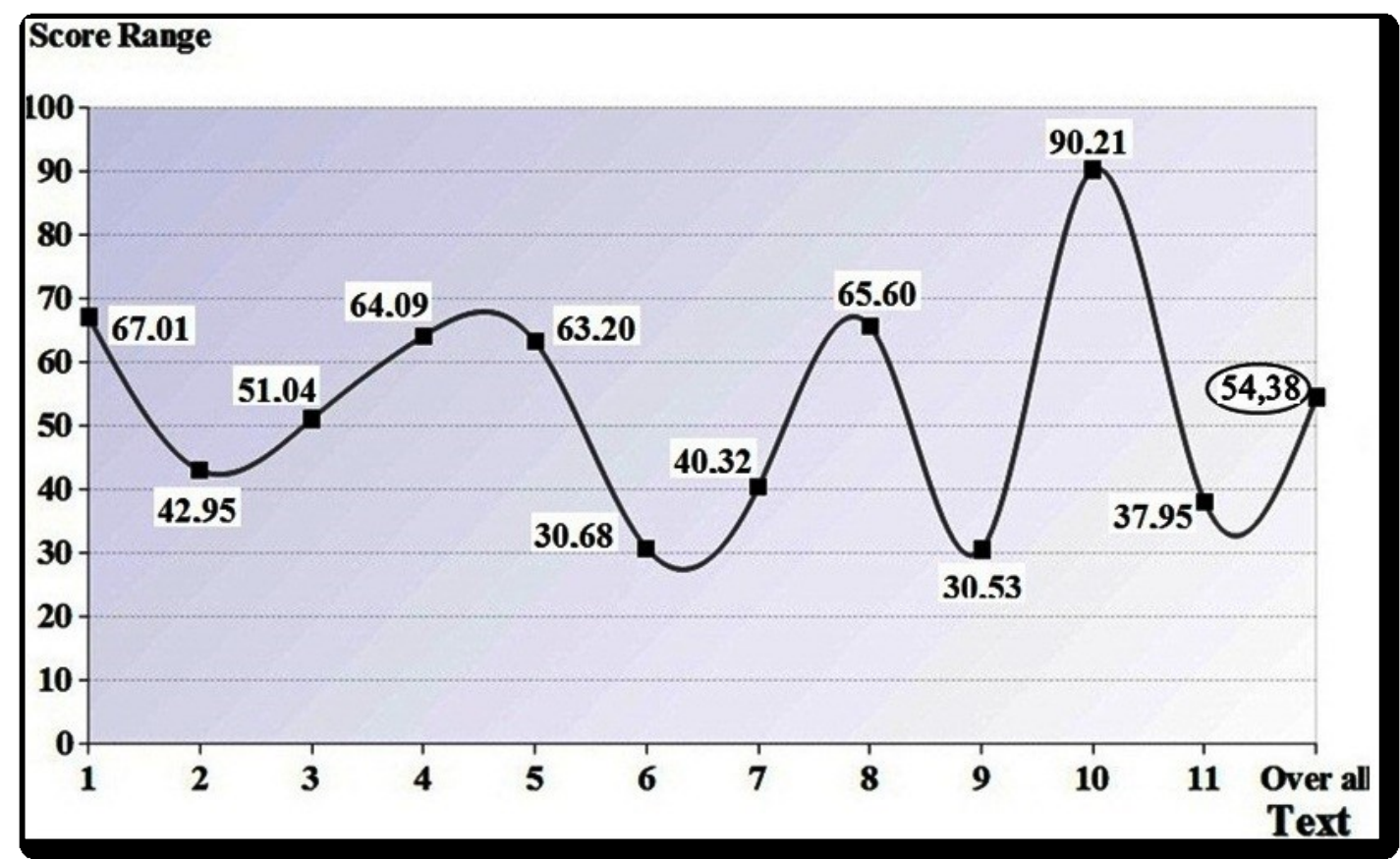

Figure 4.1

Miyazaki Readability Score Sequences

There is oscillation of readability score by looking the reading texts one by one (see Figure 4.1). The result shows that there is wide range of readability score for each text. The range of the readability score is very easy for text 09 to difficult for text 10 . The contrast is revealed when all of readability score of reading texts in English textbook for eleventh grader published by Ministry of Education and Culture, counted on average, the results shows that the quality of reading text based on theory by Miyazaki EFL Readability Index, the reading text is suitable for eleventh grader. 


\subsubsection{McAlpine® EFLAW Score}

In collecting data, the research extracts the reading texts from the English textbook for eleventh grader and focuses on the reading texts to counting the surface of the text which are number of words, number of mini-words, and number of sentences. Those text surface elements (number of words, number of mini-words, and number of sentences) are the input that is formulated to get the readability score based on McAlpine ${ }^{\circledR}$ EFLAW Formula.

In the opening of the first volume, the average of sentence length in Text 01 is 13.98 and it average word length is 3.79 . They come from the number of words that are 797, the number of mini-words which are 406, and 57 sentences. The readability score of this passage is 21.11 which is describe the level of text difficulty in quite easy to be understood.

Next in the Text 02 , it is found that the Text is consisted of 45 sentences, 314 mini-words, and 775 words. From the numbers it shows that the average of sentence length is 17.22 and the average of word length is 4.74 . All the input is formulated and then give result that the Text has McAlpine ${ }^{\circledR}$ EFLAW readability score is 24.20 which is considered as quite easy to be understood. The score makes Text 02 is harder than Text 01 since the readability score is bigger.

After examining Text 03, it is found 33 sentences, 235 mini-words, and 499 words. The calculation of average sentence length is 15.12 and average word length is 4.52 . From the input that has been calculate, the readability score of Text 03 based on McAlpine ${ }^{\circledR}$ EFLAW formula is 22.24. This score gives the 
information that Text 03 is quite easy to be understood. It means that Text 03 is harder than Text 02 but it is easier than Text 03 .

A text 04 investigation gives certain information about numbers of text surface elements which are 114 sentences, 372 mini-words, and 970 words. From those results, it is deliberated that Text 04 has 8.51 of average sentence length and 4.50 for average word length. Then, the application McAlpine ${ }^{\circledR}$ EFLAW formula for those inputs outcomes the score which is 11.77 . The score 11.77 is presenting that the text is very easy to be understood. Later on the decreasing of readability score continues from Text 02 to Text 04 .

The investigation of Text 05 raises the result of formula input which is 90 sentences, 547 mini-words, and 1142 words. The average sentence length from this text is 12.69 and followed with average word length is 4.12 . From the calculation of the input by applying the readability formula, the readability score of the text is 18.77 . The score gives meaning that Text 05 is very easy to be understood. The triple continues decreasing readability score is replaced by Text 05, which gives assumption that Text 05 is easier than the previous text.

The beginning text that can be found in second volume of English Textbook for eleventh grader published by Kementerian Pendidikan Nasional, Text 06 is constructed from 47 sentences, 303 mini-words, and 847 words. They make the average sentence length as 18.02 and the number of average word length as 5.31. The score that resulted from those numbers is 24.47 . This result makes Text 06 quite easy to be understood, as the opening passage in the second volume of the English Textbook. 
In Text 07, the statistic gives results which are 35 sentences, 192 miniwords, and 560 words. From those number, the average of sentence length is projected as 16.00 and the average word length is 5.00 . The input is calculated with McAlpine ${ }^{\circledR}$ EFLAW formula and gaining score 21.49. The score give interpretation that Text 07 is quite easy to be understood. The score is decreased than the previous passage makes Text 07 is easier than Text 06.

Following passage, Text 08 is inclosing with 95 sentences, 450 miniwords and 1028 words. It means that the average sentence length of Text 08 is 10.82. Later on the average of word length is estimated as 4.18 . The readability score that is gained from this passage is 15.65 . This score defines that the text is very easy to be understood. Furthermore, the score decreasing continuous to Text 08.

The average sentence length of Text 09 is 19.53 and followed with the average of word length is 5.16. Those numbers are result of the surface of text numbers which are consisted of 34 sentences, 277 mini-words, and 664 words. After that, the input is calculated to get the results which is 27.68. From the score, it can be estimated that Text 09 is considered has a little difficulty be understood. This makes Text 09 breaks the continuous decreasing readability score in the previous three texts. For the records, Text 09 gains the highest readability score from all of the text which indicates that it is the harder text based on McAlpine Readability Interpretation.

Text 10 consists with 28 sentences, 98 mini-words, and 165 words. From those data makes it makes the result of sentence average length become 5.89 and 
average word length turn into 3.38. The score from the input that are number of letters, words, and sentence, caused the score that gained by Text 10 is 9.32 . From this score, Text 10 can be considered very easy to be understood. It shows the contrast to the previous text. It describes that this text is considered as the easiest text that assumed can be readable to the students

Text 11 as the last text that is explored and gaining readability score as much as 26.88. It comes from average sentence length which is 19.35 and average word length is 4.78 . Text 11 is created by using 658 words, 256 mini-words, and 34 sentences. The score describes that the text is occupying the second place of the hardest text that should be read by the students.

Table 4.5

McAlpine ${ }^{\circledR}$ EFLAW Score Description

\begin{tabular}{|c|c|c|c|c|c|}
\hline \multirow{2}{*}{ No. } & \multirow{2}{*}{ Text Code } & \multicolumn{3}{|c|}{ McAlpine $₫$ EFLAW Input } & \multirow{2}{*}{$\begin{array}{c}\text { McAlpine }{ }^{\circledR} \\
\text { EFLAW } \\
\text { Scores }\end{array}$} \\
\hline & & $\begin{array}{c}\text { Number of } \\
\text { Words }\end{array}$ & $\begin{array}{l}\text { Number of } \\
\text { Mini-words }\end{array}$ & $\begin{array}{l}\text { Number of } \\
\text { Sentences }\end{array}$ & \\
\hline 1. & Text 01 & 797 & 406 & 57 & 21,11 \\
\hline 2. & Text 02 & 775 & 314 & 45 & 24.20 \\
\hline 3. & Text 03 & 499 & 235 & 33 & 22.24 \\
\hline 4. & Text 04 & 970 & 372 & 114 & 11.77 \\
\hline 5. & Text 05 & 1142 & 547 & 90 & 18.77 \\
\hline 6. & Text 06 & 847 & 303 & 47 & 24.47 \\
\hline 7. & Text 07 & 560 & 192 & 35 & 21.49 \\
\hline 8. & Text 08 & 1028 & 459 & 95 & 15.65 \\
\hline 9. & Text 09 & 664 & 277 & 34 & 27.68 \\
\hline 10. & Text 10 & 165 & 96 & 28 & 9.32 \\
\hline 11. & Text 11 & 658 & 256 & 34 & 26.88 \\
\hline \multicolumn{2}{|c|}{ Overall } & 8105 & 3457 & 612 & 18.89 \\
\hline
\end{tabular}

Based on the texts result, they can be summarized as the longest text is Text 5 because it has the most numbers of letters and words. And the shortest text is hold by Text 10 since it has the fewest letters and words numbers. Then, for the 
all text readability score based on McAlpine ${ }^{\circledR}$ EFLAW formula, Text 10 is considered is the easiest text from the textbook with score 9.32 and Text 09 is projected as the hardest text to be read with readability score 27.68. After gaining all readability score from Text 01 to Text 11 , finally the readability score of all reading text from the textbook based on McAlpine ${ }^{\circledR}$ EFLAW formula is 18.89 (see Table 4.5).

\subsubsection{McAlpine ${ }^{\circledR}$ EFLAW Interpretation}

Table 4.6

McAlpine ${ }^{\circledR}$ EFLAW Interpretation

\begin{tabular}{|c|c|c|c|}
\hline \hline No & Text Code & Readability Score & Description \\
\hline \hline 1. & Text 01 & 21.11 & Quite easy to Understand \\
\hline 2. & Text 02 & 24.20 & Quite easy to Understand \\
\hline 3. & Text 03 & 22.24 & Quite easy to Understand \\
\hline 4. & Text 04 & 11.77 & Very easy to Understand \\
\hline 5. & Text 05 & 18.77 & Very easy to Understand \\
\hline 6. & Text 06 & 24.47 & Quite easy to Understand \\
\hline 7. & Text 07 & 21.49 & Quite easy to Understand \\
\hline 8. & Text 08 & 15.65 & Very easy to Understand \\
\hline 9. & Text 09 & 27.68 & A Little Difficult \\
\hline 10. & Text 10 & 9.32 & Very easy to Understand \\
\hline 11. & Text 11 & 26.88 & A Little Difficult \\
\hline \hline \multicolumn{2}{|c|}{ Overall } & $\mathbf{1 8 . 8 9}$ & Very easy to Understand \\
\hline \hline
\end{tabular}

The quality of the text is described in three ways. The first is very easy to understand when the readability score is among score $0-20$. The second is when the readability score between 21 and 25, it is interpreted as quite easy to understand. And the third place which is when the score is taking place between 26 and 29 that it is a little difficult. The findings show that there are four texts are 
considered as very easy to be understood, then there are five texts is interpreted as quite easy to be understood, finally the rest couple texts are measured as a little difficult to be understood.

In the first volume of the textbook, it finds that the overall readability score from text 01 to Text 05 is 17.87 that makes it is very easy to be understood by the eleventh grader students. In the second volume, the finding shows that the accumulation of the readability variables from Text 06 to Text 11, makes the second volume overall readability score 20.16 . This is increasing from the previous volume results. It makes the second volume is consistently harder than the first volume. As the conclusion, by measuring all the texts at once, it is reflected that overall text is very easy to be understand (see Table 4.6).

\section{Score Range}

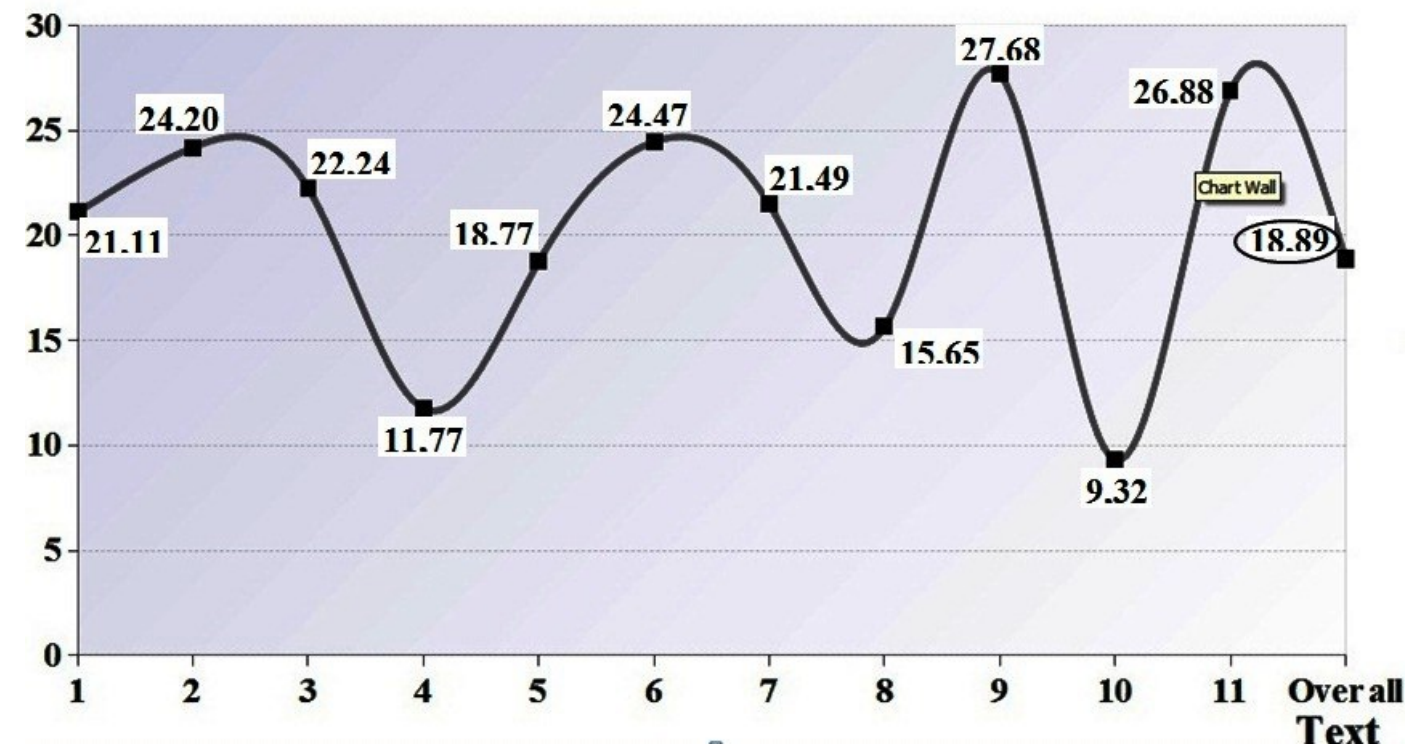

Figure 4.2

McAlpine ${ }^{\circledR}$ EFLAW Score Sequences 
There is oscillation of readability score by looking the reading texts one by one (see figure 4.2). The result shows that there is wide range of readability score for each text. The range of the readability score are very easy to understand for text 10 to a little difficult for text 09 .

\subsubsection{Results Comparison}

The results and the interpretation of two methods in assessing readability have been displayed in the previous section. Both of results can be presented as follows.

Table 4.7

Readability Score Comparison

\begin{tabular}{|c|c|c|c|c|c|}
\hline No & Text & $\begin{array}{c}\text { Miyazaki } \\
\text { Readability } \\
\text { Score }\end{array}$ & Trend & $\begin{array}{c}\text { McAlpine }{ }^{\circledR} \\
\text { EFLAW } \\
\text { Score }\end{array}$ & Trend \\
\hline 1. & Text 01 & 267.01 & - & 21.11 & - \\
\hline 2. & Text 02 & 42.95 & Harder & 24.20 & Harder \\
\hline 3. & Text 03 & 51.04 & Easier & 22.24 & Easier \\
\hline 4. & Text 04 & 64.09 & Easier & 11.77 & Easier \\
\hline 5. & Text 05 & 63.20 & Harder & 18.77 & Harder \\
\hline 6. & Text 06 & 30.68 & Harder & 24.47 & Harder \\
\hline 7. & Text 07 & 40.32 & Easier & 21.49 & Easier \\
\hline 8. & Text 08 & 65.60 & Easier & 15.65 & Easier \\
\hline 9. & Text 09 & 30.53 & Harder & 27.68 & Harder \\
\hline 10. & Text 10 & 90.21 & Easier & 9.32 & Harder \\
\hline 11. & Text 11 & 37.95 & Harder & 26.88 & Harder \\
\hline & erall & \multicolumn{2}{|c|}{54.38} & \multicolumn{2}{|c|}{18.89} \\
\hline
\end{tabular}

The table 4.6 describes the results between two readability score for each text in order. The columns mainly describe the readability score. The readability score shows the quality of the text based on readability formula. Trend shows the 
dynamic condition of readability score by comparing it with the previous text's readability score.

Most of the results based on two readability formulas give the similar trend. Since the trend of the score is in parallel condition, the results of both methods consistently and convincingly contribute the same results in determining the hardest and the easiest text.

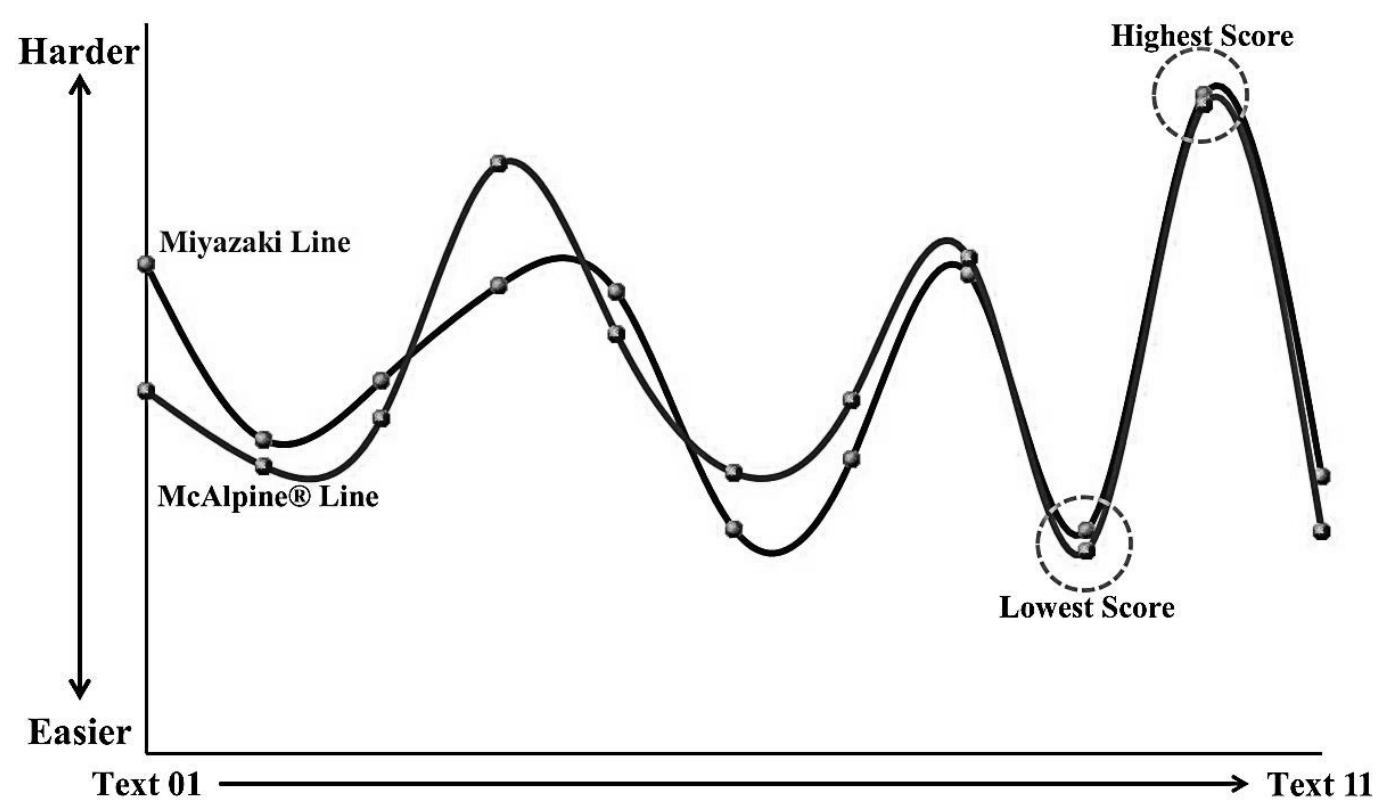

Figure 4.3

Readability Score Trend

Figure 4.3 gives the image of the trend about the score chronologically for both methods. The trend of the methods displays similarity that gives the same waves or oscillations, as well as the lowest and the highest scores. This trend has been predicted if the formula is analyzed in details. Basically, both of the formula are using the basic variables in common readability formulas. The base variables are number of text elements that are words and sentences. The modification makes 
them different since the adding of another variable which is considered by their inventor. Miyazaki formula is emphasizing in number of letters as the extended variable meanwhile McAlpine ${ }^{\circledR}$ prefers to mini-words with the arguments that number of miniwords significantly affecting the difficulty of a text.

The other results of the similar trend between those two formulas are the similarity of the hardest text and the easiest text from the textbook. It is found that text 09 is measured as the hardest text, and text 10 is reflected as the easiest text from all the text in the textbook.

\section{LIFE AND TIMES OF KI HAJAR DEWANTARA (RADEN MAS SUWARDI SURYANINGRAT)}

The development of good character should be the heart and soul of education, and should dominate the spirit of teaching. This was the philosophy of the "Father of Education" in Indonesia, Ki Hajar Dewantara. The reason, he said, was that teaching and character building are like two sides of a coin and cannot, and should not be separated.

Education, by definition, means guiding student lives in a strong foundation of good character, so that they would be civilized humans of highest moral fibre, thus laying the foundation of a great nation without distinction of religion, ethnicity, customs, economic and social status.

Ki Hajar Dewantara was born in the royal family of Yogyakarta on 2 May 1889. His given name was Raden Mas Suwardi Suryaningrat which he later changed to renounce his connections with the royal family. He transformed himself into an activist, columnist, politician and pioneer of education for Indonesians. He fought for rights of Indonesians during Dutch and Japanese colonial eras (www.tokohindonesia.com).

He was born into an aristocratic family that granted him the privilege of free access to education of his choice. He got his primary education from ELS (Europeesche Lagere School), then he continued his education at Stovia (Java Medical School) but due to health reasons he couldn't finish it. He started writing for newspapers and eventually all his writings were focused on Indonesian patriotism, thus anti Dutch. He was involved in the early activities of Budi Utomo and the Indiesche Party, which were both important in the early development of the pergerakan, the "movement" that grew up with a nascent Indonesian national political consciousness (www.indonotes.wordpress.com).

He was exiled between 1913 and 1919 following the publication of two of his articles: "Als ik eens Nederlander" (If I was a Dutchman) and "Eén voor allen en allen voor één" (One for all and all for one). He used his time in exile to learn more about education and obtained a Europeesche certificate (www.tokohindonesia.com).

Following his return, he focused more on cultural and educational efforts paving way to develop educational concepts in Indonesia. He believed that education is very 
important and the most important means of freeing Indonesians from clutches of colonization. He played a leading role in establishing "National Onderwijs Institut Taman Siswa" in 1922. This institution was established to educate native Indonesians during colonial times. This institution was based on these principles:

1. Ing Ngarsa Sung Tuladha (the one in front sets example).

2. Ing Madya Mangun Karsa (the one in the middle builds the spirit and encouragement).

3. Tut Wuri Handayani (the one at the back gives support)

(indonotes.wordpress.com).

As Ki Hajar believed that character was not merely a theoretical concept, but a practical and living concept, he embodied his vision in his school, Taman Siswa. The central goals of Taman Siswa emphasized character building, including traits such as patriotism and love for the nation, and a sense of national identity. His vision was that Indonesians would be free from colonial powers, to fight for independence and have good character. He continued writing but his writings took a turn from politics to education. These writings later laid foundation of Indonesian education. Froebel, Montessori and Tagore influenced his educational principles and in Taman Siswa he drew some inspiration from Tagore's Shantiniketan (asrirahayudamai.wordpress.com).

After independence, he was given the office of Minister of Education and Culture. For his efforts in pioneering education for the masses, he was officially declared Father of Indonesian Education and his birthday is celebrated as National Education Day. His portrait was on 20,000 rupiah note till 2002. He was officially confirmed as a National Hero of Indonesia by the $2^{\text {nd }}$ President of Indonesia on $28^{\text {th }}$ November 1959 (ww.tokohindonesia.com).

Ki Hajar Dewantara passed away on 26th April 1952 at the age of 69 years. His wife donated all Ki Hajar's belongings to Dewantara Kirti Griya Museum, Yogyakarta. He was a great man who spent his whole life serving his people and country.

Figure 4.4

The Hardest Text

The average of sentence length in Text 09 is 19.53 and it average word length is 5.16. The averages come from the number of words which are 664, and 34 sentences. The readability index describes the level of this text is in difficult place.

Meanwhile, the investigation of Text 10 has 28 sentences and 165 words. It gives the average sentence length from this text is 5.89 and followed with average word length is 3.38. The score from both two readability formulas provides meaning that Text 10 is very easy to understand, which is contradictive 
to the previous text. Contradictive means that Text 09 gains the lowest readability score from all of the text, and Text 10 is in the highest place of readability score. Therefore, both text can be highlight as the easiest and the hardest texts that to be read by the students.

\section{“STAND BY ME” BY BEN E KING}

When the night has come

And the land is dark

And the moon is the only light we'll see

No I won't be afraid

Oh, I won't be afraid

Just as long as you stand, stand by me

So darling, darling

Stand by me, oh stand by me

Oh stand, stand by me

Stand by me

If the sky that we look upon

Should tumble and fall

All the mountains should crumble to the sea

I won't cry, I won't cry

No, I won't shed a tear

Just as long as you stand, stand by me

So darling, darling

Stand by me, oh stand by me

Oh stand, stand by me

Stand by me

So darling, darling

Stand by me, oh stand by me

Oh stand now, stand by me, stand by me

Whenever you're in trouble won't you stand by me

Oh stand by me, oh won't you stand now, stand

Stand by me

Stand by me

Figure 4.5

The Easiest Text 
Both of the figures above, minimally can give a description about the easiest and hardest text from the textbook. The reader can easily give prejudice by looking at the length of the text to decide which one is easy or hard. Looking at text 09 , it can give negative motivations in reading, since the length, the density of words, and also the content of the text. The content words in text 09 has a tendency to complicated text since it use intercultural terms with scientific approach makes it is hard to be digested by the students. So that it needs companion materials in reading the text.

The contrast comes in the text 10. The text is in form of song lyrics. Its length and word density makes as well as the sentences is made by arranging simple and common words become the contribution of the difficulty reduction from the text.

\subsection{Reading Text Suitability}

Based on the second research question, this research is studying the suitability of reading text in English textbook for eleventh grader published by Ministry of Education and Culture basically by extracting the appropriate target language/teaching material for the curriculum and checking them to the reading text whether they are accommodate or not. It starts from curriculum analysis which is going to extract the priority target language or learning objective. It follows with Reading text checking that provides the information of reading text scope in facilitating student in achieving learning goal. Finally, it closes with the interpretation of findings. 
Table 4.8

Issues of research question 2

\begin{tabular}{lll}
\hline \multicolumn{2}{c}{ Research Question } & \multicolumn{1}{c}{ Issues } \\
\hline How is suitability of reading texts in & 1. Analysis of eleventh grader English \\
English Textbook for Eleventh Grader & curriculum \\
published by Ministry of Education and & 2. Assessing target language in reading \\
$\begin{array}{ll}\text { Culture fulfill the competences that } \\
\text { required in the curriculum? }\end{array}$ & $\begin{array}{l}\text { text } \\
\text { reading text suitability }\end{array}$ \\
\hline
\end{tabular}

\subsubsection{Analysis of Eleventh Grader English Curriculum}

In answering the second research question, the first step is defining target language of teaching English based on curriculum. It is the parameter in checking the domain that the reading text should covers in order to help the students in gaining the learning objective.

It is believe that curriculum is made by using taxonomy in order to make learning sequences which useful for both teachers and students for curriculum 2013, government states that there are 4 basic taxonomies in developing curriculum to be implemented in schools. They are spiritual aspect, social aspect, knowledge aspect and the skills aspect.

In analyzing the core competence and bas competence, this study limits the range of taxonomies only covers for knowledge aspect and skill aspect which covering base competence number 3 and base competence number 4 . From both types of base competences, it is extracted the proper material or target language that should be in the reading text so that can be material that can help the student in achieving learning goals. The table below gives the data about the competences as the differentiation from the base competences. 
Table 4.9

Base competences and its target language

\begin{tabular}{|c|c|c|}
\hline \multicolumn{2}{|r|}{ Base Competences } & $\begin{array}{l}\text { Material/Target } \\
\text { Language }\end{array}$ \\
\hline \multirow[t]{3}{*}{3.1} & \multirow{7}{*}{$\begin{array}{l}\text { Menganalisis fungsi sosial, struktur teks, dan unsur } \\
\text { kebahasaan pada ungkapan memberi saran dan } \\
\text { tawaran, serta responnya, sesuai dengan konteks } \\
\text { penggunaannya. } \\
\text { Menyusun teks lisan dan tulis untuk menyatakan, } \\
\text { menanyakan, dan merespon ungkapan memberi saran } \\
\text { dan tawaran, dengan memperhatikan fungsi sosial, } \\
\text { struktur teks, dan unsur kebahasaan yang benar dan } \\
\text { sesuai konteks }\end{array}$} & Expres \\
\hline & & g offer \\
\hline & & $\begin{array}{l}\text { Expre } \\
\text { sugge }\end{array}$ \\
\hline \multirow[t]{4}{*}{4.1} & & $\begin{array}{l}\text { Responding } \\
\text { suggestion }\end{array}$ \\
\hline & & action \\
\hline & & Text S \\
\hline & & feature \\
\hline \multirow[t]{3}{*}{3.2} & \multirow{5}{*}{$\begin{array}{l}\text { Menganalisis fungsi sosial, struktur teks, dan unsur } \\
\text { kebahasaan untuk menyatakan dan menanyakan } \\
\text { tentang pendapat dan pikiran, sesuai dengan konteks } \\
\text { penggunaannya } \\
\text { Menyusun teks lisan dan tulis untuk menyatakan dan } \\
\text { merespon ungkapan menyatakan pendapat dan pikiran, } \\
\text { dengan memperhatikan fungsi sosial, struktur teks, dan } \\
\text { unsur kebahasaan yang benar dan sesuai konteks }\end{array}$} & Givin \\
\hline & & $\begin{array}{l}\text { Ask1 } \\
\text { opin }\end{array}$ \\
\hline & & Soci \\
\hline \multirow[t]{2}{*}{4.2} & & Text \\
\hline & & Lang \\
\hline \multirow[t]{2}{*}{3.3} & \multirow{5}{*}{$\begin{array}{l}\text { Menganalisis fungsi sosial, struktur teks, dan unsur } \\
\text { kebahasaan pada ungkapan harapan dan doa bersayap } \\
\text { (extended), serta responnya, sesuai dengan konteks } \\
\text { Menyusun teks lisan dan tulis untuk mengucapkan dan } \\
\text { merespon ungkapan harapan dan doa bersayap } \\
\text { (extended), dengan memperhatikan fungsi sosial, } \\
\text { struktur teks, dan unsur kebahasaan yang benar dan } \\
\text { sesuai konteks }\end{array}$} & $\begin{array}{l}\text { g } \\
\text { ams } \\
\end{array}$ \\
\hline & & Respor \\
\hline \multirow{3}{*}{4.3} & & ction \\
\hline & & Text \\
\hline & & $I_{0}$ \\
\hline 3.4 & \multirow{6}{*}{$\begin{array}{l}\text { Menganalisis fungsi sosial, struktur teks, dan unsur } \\
\text { kebahasaan dari teks undangan resmi, sesuai dengan } \\
\text { konteks penggunaannya } \\
\text { Menangkap makna teks undangan resmi. } \\
\text { Menyunting undangan resmi dengan memperhatikan } \\
\text { fungsi sosial, struktur teks, dan unsur kebahasaan yang } \\
\text { benar dan sesuai konteks } \\
\text { Menyusun teks tulis undangan resmi, dengan } \\
\text { memperhatikan fungsi sosial, struktur teks, dan unsur } \\
\text { kebahasaan yang benar dan sesuai konteks. }\end{array}$} & Forr \\
\hline 4.4 & & Accep \\
\hline 4.5 & & $\begin{array}{l}\text { Decli } \\
\text { invita }\end{array}$ \\
\hline \multirow{3}{*}{4.6} & & Social \\
\hline & & \\
\hline & & Lang \\
\hline \multirow[t]{3}{*}{3.5} & \multirow{3}{*}{$\begin{array}{l}\text { Menganalisis fungsi sosial, struktur teks, dan unsur } \\
\text { kebahasaan dari teks surat pribadi, sesuai dengan } \\
\text { konteks }\end{array}$} & Perss \\
\hline & & ction \\
\hline & & \\
\hline
\end{tabular}




\begin{tabular}{|c|c|c|}
\hline $\begin{array}{l}4.7 \\
4.8\end{array}$ & $\begin{array}{l}\text { Menangkap makna teks surat pribadi } \\
\text { Menyusun teks surat pribadi, dengan memperhatikan } \\
\text { fungsi sosial, struktur teks, dan unsur kebahasaan yang } \\
\text { benar dan sesuai konteks. }\end{array}$ & Language feature \\
\hline \multirow[t]{3}{*}{3.6} & \multirow{5}{*}{$\begin{array}{l}\text { Menganalisis fungsi sosial, struktur teks, dan unsur } \\
\text { kebahasaan dari teks prosedur berbentuk manual dan } \\
\text { kiat-kiat (tips), sesuai dengan konteks penggunaannya. } \\
\text { Menangkap makna teks prosedur, lisan dan tulis, } \\
\text { berbentuk manual dan kiat-kiat (tips). } \\
\text { Menyunting teks prosedur berbentuk manual dan kiat- } \\
\text { kiat (tips), dengan memperhatikan fungsi sosial, } \\
\text { struktur teks, dan unsur kebahasaan yang benar dan } \\
\text { sesuai konteks }\end{array}$} & Procedure Text \\
\hline & & Function \\
\hline & & Text Structure \\
\hline 4.9 & & \multirow[t]{2}{*}{ Language feature } \\
\hline 4.10 & & \\
\hline \multirow[t]{4}{*}{3.7} & \multirow{7}{*}{$\begin{array}{l}\text { Menganalisis fungsi sosial, struktur teks, dan unsur } \\
\text { kebahasaan untuk menyatakan dan menanyakan } \\
\text { tentang tindakan/kegiatan/kejadian tanpa perlu } \\
\text { menyebutkan pelakunya dalam teks ilmiah, sesuai } \\
\text { dengan konteks penggunaannya } \\
\text { Menganalisis struktur teks dan unsur kebahasaan untuk } \\
\text { melaksanakan fungsi sosial teks factual report dengan } \\
\text { menyatakan dan menanyakan tentang teks ilmiah } \\
\text { faktual tentang orang, binatang, benda, gejala dan } \\
\text { peristiwa alam dan sosial, sederhana, sesuai dengan } \\
\text { konteks pembelajaran di pelajaran lain di Kelas XI } \\
\text { Menyusun teks lisan dan tulis, untuk menyatakan dan } \\
\text { menanyakan tentang tindakan/kegiatan/kejadian tanpa } \\
\text { perlu menyebutkan pelakunya dalam teks ilmiah, } \\
\text { dengan memperhatikan fungsi sosial, struktur teks, dan } \\
\text { unsur kebahasaan yang benar dan sesuai konteks. } \\
\text { Menangkap makna dalam teks ilmiah faktual (factual } \\
\text { report), lisan dan tulis, sederhana, tentang orang, } \\
\text { binatang, benda, gejala dan peristiwa alam dan sosial, } \\
\text { terkait dengan Matapelajaran lain di Kelas XI. }\end{array}$} & Scientific report \\
\hline & & Social Function \\
\hline & & Tex \\
\hline & & feature \\
\hline 3.9 & & \\
\hline 4.11 & & \\
\hline 4.13 & & \\
\hline \multirow[t]{2}{*}{3.8} & \multirow{5}{*}{$\begin{array}{l}\text { Menganalisis fungsi sosial, struktur teks, dan unsur } \\
\text { kebahasaan untuk menyatakan dan menanyakan } \\
\text { tentang pengandaian jika terjadi suatu keadaan/ } \\
\text { kejadian/peristiwa di waktu yang akan datang, sesuai } \\
\text { dengan konteks sesuai dengan konteks penggunaannya. } \\
\text { Menyusun teks lisan dan tulis untuk menyatakan dan } \\
\text { menanyakan tentang pengandaian jika terjadi suatu } \\
\text { keadaan/ kejadian/peristiwa di waktu yang akan datang, } \\
\text { dengan memperhatikan fungsi sosial, struktur teks, dan } \\
\text { unsur kebahasaan yang benar dan sesuai konteks }\end{array}$} & $\begin{array}{l}\text { Exp1 } \\
\text { cond } \\
\text { sent }\end{array}$ \\
\hline & & $\begin{array}{l}\text { Asking with } \\
\text { conditional }\end{array}$ \\
\hline \multirow{3}{*}{4.12} & & $\begin{array}{l}\text { sentence } \\
\text { Social Function }\end{array}$ \\
\hline & & Tex \\
\hline & & age feature \\
\hline \multirow[t]{2}{*}{3.10} & \multirow{2}{*}{$\begin{array}{l}\text { Menganalisis fungsi sosial, struktur teks, dan unsur } \\
\text { kebahasaan dari teks eksposisi analitis tentang topik } \\
\text { yang hangat dibicarakan umum, sesuai dengan konteks }\end{array}$} & $\begin{array}{l}\text { Analytical } \\
\text { expository }\end{array}$ \\
\hline & & \\
\hline
\end{tabular}




\begin{tabular}{|c|c|c|}
\hline \multirow[b]{2}{*}{4.14} & \multirow{2}{*}{$\begin{array}{l}\text { penggunaannya } \\
\text { Menangkap makna dalam teks eksposisi analitis } \\
\text { tentang topik yang hangat dibicarakan umum }\end{array}$} & Text Structure \\
\hline & & Language feature \\
\hline \multirow[t]{4}{*}{3.11} & \multirow{5}{*}{$\begin{array}{l}\text { Menganalisis fungsi sosial, struktur teks, dan unsur } \\
\text { kebahasaan dari teks biografi pendek dan sederhana } \\
\text { tentang tokoh terkenal, sesuai dengan konteks } \\
\text { penggunaannya. } \\
\text { Menangkap makna teks biografi pendek dan sederhana } \\
\text { tentang tokoh terkenal. }\end{array}$} & phy text \\
\hline & & Social Function \\
\hline & & Text Structure \\
\hline & & Languas \\
\hline 4.15 & & \\
\hline 3.12 & $\begin{array}{l}\text { Menyebutkan fungsi sosial dan unsur kebahasaan } \\
\text { dalam lagu. } \\
\text { Menangkap pesan dalam lagu. }\end{array}$ & Song lyr \\
\hline
\end{tabular}

There are eleven groups base competence (see Table 4.8). The member of groups represents the material that should be comprehended by the students. The base competence groups consist of receptive skills and productive skills. This kind of language process makes the base competences group it divided into spoken cycle and written cycle. Spoken cycle emphasizes in oral receptive (listening) and productive (speaking) process, meanwhile written cycle points out in reading skill and writing skill.

From the base competences that enclosed in curriculum, the extraction of them results the material or target language as the learning objectives in the classroom. Those language targets is the parameter that the reading texts should be covered in other to gain batter suitability as the criteria of a good text based on theory from Nuttall (2005)

\subsubsection{Target Language in Reading Text}

After the process of extracting target language from the base competence, the net process is listing the target language. All the reading text is read and then 
they are examined to get the information about the target language. The reading texts are studied one by one by reading and understanding.

The first volume of this textbook is used to the first term. The textbook contains five chapters in 111 pages. Every chapter contains reading text as the medium in presenting target language that should be comprehended, practiced and used by the students in achieving learning goals. The most of the chapters is begin with the picture that illustrated the reading text in it.

The first chapter of the textbook is filling with folklore texts entitled The Enchanted Fish where the students is presenting the narrative text that contains several script of the character that using target language as the learning material. The instructional goals of this chapter of the textbook are comprehending folklore reading text, learning using offers and suggestions expressions with their responses, holding a discussion, writing a simple folklore and finally creating a postcard of poster.

The second chapter of the textbook is opened with general information of a reading text entitled Bullying: A cancer that must be eradicated that is claimed contains a message that represents author opinion about bullying which have been recent issues in educational environment. This chapter of the textbook gives learning goal to student some experience of reading opinion, discussing the theme, practicing expressing opinion about social issues by expressing or speaking, writing, and even delivering their opinion in form of poster.

The script of Indonesian first President, Sukarno's speech at the opening of the Bandung Conference in April 18, 1955 is the main theme of reading text in 
the third chapter of the textbook. The language target that is expected to be grasped by students includes doing discussion from the speech, learning how to convey and write several expression such as congratulate, hopes and dreams in form of spoken and written text or poster.

Followed by chapter four of the textbook, the reading text that is presented displays some target language which are learning how to accepting and declining an invitation and then creating an invitation text and diorama. The reading text is exposed with the form of a play script. This kind of text is presented to the students with intention to introduce the literature genre as kind of text genre beside informational ones.

In closing the first volume of the textbook, the text entitled Letter to God is contained of personal letter that is a language target of reading competence from chapter five of the textbook. Students are expected to produce some activity such as writing a personal letter, creating a skit and illustrating a scene of the story they create. They can get the example from the reading text that has been mentioned before which is presented by using narrative with some personal letters that attached in the story with social purposed to inform and entertain the reader.

The second volume of this textbook is used to the second term. The textbook contains six chapters in 128 pages. Every chapter contains reading text as the medium in presenting target language that should be comprehended, practiced and used by the students in achieving learning goals since the text-based learning is emphasized to maximize the classroom activity in English learning. 
The most of the chapters is begin with the picture that illustrated the reading text in it.

Chapter six of the textbook as the opening of the second volume presents technical writing entitled Story Of Technical Writing with steps and tips how people write an technical writing in reporting, arguing, or expressing their thought in some purposes for example academic purposes. From the text, students can dig the elements of procedural text, and is expected to write a procedural text that contains clear direction and simple tips for the reader.

Information report text appears in chapter seven of the textbook by carrying natural disaster as the theme of the reading text. The report writing as the non-fiction genre can be used by the students in describing event or phenomena that happens around them with the presentation that is structured with a good arrangement to make the reader catch the idea as clear as possible. By intention for that purposed, the students are thought to write a clear information text or information report by attaching evidence to support the information.

The short story from fiction genre encapsulated in chapter eight of the textbook that conveying literature figures. The students are introduced with the character and history of short story as a kind of literary work. Language target that is focused in this chapter of the textbook is about the application of conditional sentence. It gives the students space in expressing their creativity in arranging and writing not only text but also short story that contains unconditional sentences in it. 
Biography is the genre of the reading text of chapter of the textbook nine. In this chapter of the textbook, the text entitled Life and Times of Ki Hajar Dewantara (Raden Mas Suwardi Suryaningrat) as the founding father particularly for national education. This reading text is presented as the example of biography text. It is projected that the students are able to read and understand a biography text and they can produced another biography text individually or in group.

Songs as same as poems is introduced in chapter ten of the textbook. A poem is considered as a part of literary work that in unique form how people expressed their idea and feeling to others. In this chapter of the textbook, students are not expected to produce a song or poetry, but minimally, they have sensitivity in feels the massages from the author to them with the text in it.

Finally in chapter eleven of the textbook, the exposition text appears with natural phenomena theme. Global warming discussion is presented in exposition text by attributing pint of view, arguments and evidences. The structure of the text should be mastered by the students in order to train them to produce analytical exposition text which is written individually or in groups.

A good text need to present the target language as the indicator that a text can be exploited based on the learning objective. Finding shows that all the texts cannot accommodate the require target language that should be presented. From 22 items of target language, there are 12 items that are not covered by the texts that can be exploited by teachers or students in helping those achieving learning goals. The domination of target language is taking by social function, text 
structure, and language feature from the text itself. Finally, from the results, it can be calculated that the suitability of overall reading texts is projected at $54.54 \%$.

Table 4.10

Relevancy of reading competence with text

\section{Core Competence No 3.}

Memahami, menerapkan, dan menganalisis pengetahuan faktual, konseptual, prosedural, dan metakognitif berdasarkan rasa ingin tahunya tentang ilmu pengetahuan, teknologi, seni, budaya, dan humaniora dengan wawasan kemanusiaan, kebangsaan, kenegaraan, dan peradaban terkait penyebab fenomena dan kejadian, serta menerapkan pengetahuan prosedural pada bidang kajian yang spesifik sesuai dengan bakat dan minatnya untuk memecahkan masalah

\begin{tabular}{|c|c|c|}
\hline \multicolumn{2}{|r|}{ Relevance Reading Base Competence } & Relevance Text \\
\hline 3.4 & $\begin{array}{l}\text { Menganalisis fungsi sosial, struktur teks, dan } \\
\text { unsur kebahasaan dari teks undangan resmi, } \\
\text { sesuai dengan konteks penggunaanya }\end{array}$ & $\begin{array}{l}\text { Text } 04 \\
\text { Vanity and Pride }\end{array}$ \\
\hline 3.5 & $\begin{array}{l}\text { Menganalisis fungsi sosial, struktur teks, dan } \\
\text { unsur kebahasaan dari teks surat pribadi, sesuai } \\
\text { dengan konteks penggunaannya. }\end{array}$ & $\frac{\text { Text } 05}{\text { Letter to God }}$ \\
\hline 3.6 & $\begin{array}{l}\text { Menganalisis fungsi sosial, struktur teks, dan } \\
\text { unsur kebahasaan dari teks prosedur berbentuk } \\
\text { manual dan kiat-kiat (tips), sesuai dengan } \\
\text { konteks penggunaannya. }\end{array}$ & $\begin{array}{l}\text { Text } 06 \\
\text { Story of Technical } \\
\text { Writing }\end{array}$ \\
\hline 3.7 & $\begin{array}{l}\text { Menganalisis fungsi sosial, struktur teks, dan } \\
\text { unsur kebahasaan untuk menyatakan dan } \\
\text { menanyakan tentang tindakan/kegiatan/ kejadian } \\
\text { tanpa perlu menyebutkan pelakunya dalam teks } \\
\text { ilmiah, sesuai dengan konteks penggunaannya. }\end{array}$ & $\begin{array}{l}\text { Text } 07 \\
\text { Earthquakes: The Most } \\
\text { Deadly Natural } \\
\text { Hazards }\end{array}$ \\
\hline 3.9 & $\begin{array}{l}\text { Menganalisis struktur teks dan unsur kebahasaan } \\
\text { untuk melaksanakan fungsi sosial teks factual } \\
\text { report dengan menyatakan dan menanyakan } \\
\text { tentang teks ilmiah faktual tentang orang, } \\
\text { binatang, benda, gejala dan peristiwa alam dan } \\
\text { sosial, sederhana, sesuai dengan konteks } \\
\text { pembelajaran di pelajaran lain di Kelas XI. }\end{array}$ & $\begin{array}{l}\text { Text } 07 \\
\text { Earthquakes: The Most } \\
\text { Deadly Natural } \\
\text { Hazards }\end{array}$ \\
\hline 3.10 & $\begin{array}{l}\text { Menganalisis fungsi sosial, struktur teks, dan } \\
\text { unsur kebahasaan dari teks eksposisi analitis } \\
\text { tentang topik yang hangat dibicarakan umum, } \\
\text { sesuai dengan konteks penggunaannya. }\end{array}$ & $\begin{array}{l}\text { Text } 11 \\
\text { Global Warming: Is It } \\
\text { an End to Our World? }\end{array}$ \\
\hline 3.11 & $\begin{array}{l}\text { Menganalisis fungsi sosial, struktur teks, dan } \\
\text { unsur kebahasaan dari teks biografi pendek dan } \\
\text { sederhana tentang tokoh terkenal, sesuai dengan } \\
\text { konteks penggunaannya. }\end{array}$ & $\begin{array}{l}\text { Text } 09 \\
\text { Life and Times of Ki } \\
\text { Hajar Dewantara }\end{array}$ \\
\hline
\end{tabular}




\section{CHAPTER V}

\section{CONCLUSIONS AND SUGGESTION}

This chapter presents the conclusions and suggestions that include the results of readability of the reading text based on readability formula for EFL material and the description of suitability of the texts based on the presentation of the target languages. Meanwhile, the suggestions are aimed of the action that should be done as the follow up of the results.

\subsection{Conclusions}

There are several results based on the readability and the suitability of the reading text. In terms of readability, two methods have been applied. The first method, by using Miyazaki EFL Readability presents that the overall reading texts readability score is 54.38 and that can be interpreted as the reading text in the level of fairly difficult and suitable to eleventh grader. By using McAlpine ${ }^{\circledR}$ EFLAW Formula, the readability score achieves 18.89 with the meaning that the reading texts in English textbook or eleventh grader is very easy to understand.

Both of the volumes show consistency that the first volume is more readable than the second volume both in terms of Miyazaki Readability method and McAlpine ${ }^{\circledR}$ EFLAW Readability. Moreover, in the process of counting the readability score, both readability methods consistently and convincingly confirmed that Text 09 is the hardest text to be digested by the students and Text 10 is the easiest to understand. 
In conducting suitability research, the target language has been checked against the curriculum. It gives results that, from 22 items of target language that are expected to be covered by the text, there are only 12 items which contain the proper target language. It means that the result of text suitability is about $54.54 \%$ from overall text.

The results give the impressions that not all of target languages are found in reading materials. It is because that reading text is not the only component of a good textbook. By looking on the items of the checklist, the reading material has fulfilled the reading skills based on the language objectives. The rest of text suitability is to be found in other parts of the textbook such as assessment sheets as well as activity sheets.

After doing the research of readability application in reading text materials, it can be concluded that there are several advantages and disadvantges by using readability formula especially for both formulas before. Firstly, readability formulas are text-based formulas that makes researchers, authors and editors as well as teachers can use them easily. Then, they can help the author and editor to transform the document into plain language and measures it to define appropriate levels of the reader. Finally, it can be assumed that if one use readability formulas to perfect a document, it would help readers to increase their retention, comprehension, and speed of reading, particularly for EFL condition.

Readability formulas are not a perfect method since there are several limitation that the researcher found. It is granted that the readability formulas cannot size the whole thing that decide whether a book is readable for a student, 
but it is recommended that reading test can measure a student's reading behavior. Because of the existence of many readability formulas, it can rise the chance of attaining extensive variations of results from a text. Finally they have limitation in measure the context, difficulty of concepts, prior knowledge coherence of text, and interest level as well as the language feature of literary works such as language figure, idioms, etc. makes the readability formulas are not suitable in creative writing assessment.

\section{$5.2 \quad$ Suggestions}

The suggestions are directed to the textbook publisher, the teachers, and the next researchers

\subsubsection{For the Publisher}

Ministry of Education and Culture as not only the publisher of this textbook but also as the policy maker in procuring the best material to the students and teachers needs to consider in selection the appropriated reading materials for the students by considering theories of pedagogy and psycholinguistics as well as sociolinguistics such as three criteria concept of reading text by Nuttall (2005: $30)$.

By considering the theories, it is expected that the author or publisher can give balance composition to the reading text in terms of readability and suitability, with intended to help the students and the teachers in getting the learning goals. Furthermore, the author should be more carefully in carrying accurate materials to 
conform to the English competence of eleventh grader in curriculum 2013. Then, the author should concerns on the whole package of in constructing the textbook and the sequence of the materials in constructing the textbook the English competence for eleventh grader in curriculum 2013.

\subsubsection{For the Teacher}

From this research, this research is look forward to give some practical theories to assessing a text to be judged whether it is appropriate to the student by using methodology and application aid such as the software that used worldwide, Microsoft ${ }^{\circledR}$ Office.

Based on the reality, it is expected that the teachers know better the strength and the weakness of the reading material of English textbook for eleventh grader. By using professional judgment of the students' capacity, the teacher can do some improvement of the reading text by assessing, evaluating, selecting, adapting, modifying, etc. in order to present the best reading material that match to the students.

\subsubsection{For the Future Researcher}

For the future research, it is suggested to make the research as the follow up of this research. The follow up research such as exploring the suitability of the text by using or creating better methodology in assessing or measuring the reading text in a textbook. A comparison study is recommended in order to expanding the research limitation to get the connection of the material development for each 
grade. The research of materials should not stick in reading material, but it can be lengthened to other skills as well as the assessments that printed on the textbook. Hopefully in the near future, another better theory or methodology is created to achieve the better accuracy in assessing the reading text which in terms of useful and practical. 


\section{REFERENCES}

Alderson, John Charles. (2000). Assessing Reading. Cambridge: Cambridge University Press.

Ary, Donald, Jacobs, Lucy Cheser, \& Sorensen, Chris. (2010). Introduction to Research in Education. Belmont: Wadsworth.

Bashir, Mahrukh. (2014a). Bahasa Inggris untuk SMA/MA/SMK/MAK Kelas XI Semester 1. Jakarta: Kementerian Pendidikan dan Kebudayaan.

Bashir, Mahrukh. (2014b). Bahasa Inggris untuk SMA/MA/SMK/MAK Kelas XI Semester 2. Jakarta: Kementerian Pendidikan dan Kebudayaan.

Brown. (1998). An EFL Readability Index. JALT Journal, 20(2), 7-36.

Brown, H. Douglas. (2001). Teaching by Principles : An Interactive Approach to Language Pedagogy (2nd ed.). New York: Longman.

Bryce, Nadine. (2013). Textual Features and Language Demands of Primary Grade Science Textbooks: The Call for More Informational Texts in Primary Grades. In M. S. Khine (Ed.), Critical Analysis of Science Textbooks (pp. 101-120). London: Springer.

Burns, Paul C, Roe, Betty, \& Smith, Sandra. (2011). Teaching Reading in Today's Elementary Schools. Belmont: Cengage Learning.

Burstein, Jill. (2009). Opportunities for Natural Language Processing Research in Education. In A. Gelbukh (Ed.), Computational Linguistics and Intelligent Text Processing (pp. 6-27). Mexico City: Springer.

Cahyani, Isah. (2013). Memberdayakan Bahasa Indonesia: Pendekatan Saintifik dalam Pembelajaran Menulis. Paper presented at the Implementasi Pembelajaran Bahasa dan Sastra Indonesia Berdasarkan Kurikulum 2013, Bandung.

Chall, Jeanne S. (1988). The Beginning Years. In B. L. Zakaluk \& S. J. Samuels (Eds.), Readability : Its Past, Present, and Future. Newark: International Reading Association.

Connelly, M. (2012). Get Writing: Paragraphs and Essays: Cengage Learning.

Creswell, John W. (2012). Educational Research : Planning, Conducting, and Evaluating Quantitative and Qualitative Research. Boston: Pearson. 
Davison, Alice. (1988). Assigning Grade Levels without Formulas: Some Case Studies. In B. L. Zakaluk \& S. J. Samuels (Eds.), Readability : Its Past, Present, and Future. Newark: International Reading Association.

Devetak, Iztok, \& Vogrinc, Janez. (2013). The Criteria for Evaluating the Quality of the Science Textbooks In M. S. Khine (Ed.), Critical Analysis of Science Textbooks (pp. 3-15). London: Springer.

DuBay, William H. (2004). The Principles of Readability. Costa Mesa: Impact Information.

DuBay, William H. (2007). The Classic Readability Studies. Costa Mesa: Impact Information.

Firdianti, Fiqih Delvia, \& Purwati, Oikurema. (2013). Analysis of the Reading Materials in Textbook "English in Focus" English for the Ninth Graders of Junior High School Published by National Education Department. RETAIN, 1(3).

Fry, Edward. (2004). Understanding the Readability of Content Area Texts In D. Lapp, J. Flood \& N. Farnan (Eds.), Content Area Reading and Learning: Instructional Strategies (pp. 4). Mahwah: Lawrence Erlbaum.

Gardner, Howard. (2009). Multiple approaches to understanding. In K. Illeris (Ed.), Contemporary theories of learning : learning theorists in their own words (1st. ed., pp. viii, 235 p.). London: Routledge.

Gebhardt, Jürgen. (1987). Politische Kultur und Zivilreligion. In D. BergSchlosser \& J. Schissler (Eds.), Politische Kultur in Deutschland (Vol. 18/1987, pp. 49-60). New York: VS Verlag für Sozialwissenschaften.

Greenfield, Jerry. (2003). The Miyazaki EFL Readability Index. Comparative Culture, 9, 41-49.

Greenfield, Jerry. (2004). Readability Formulas for EFL. JALT Journal, 26(1), 524.

Halliday, Michael Alexander Kirkwood, \& Matthiessen, Christian M. I. M. (2004). An Introduction to Functional Grammar. London: Arnold.

Hutchinson, Tom, \& Torres, Eunice. (1994). The Textbook as Agent of Change. ELT Journal, 48(4), 315-328.

Johnson, Burke, \& Christensen, Larry B. (2008). Educational Research : Quantitative, Qualitative, and Mixed Approaches. Los Angeles: Sage Publications. 
Katuuk, Deitje Adolfien. (2014). Manajemen Implementasi Kurikulum: Strategi Penguatan Implementasi Kurikulum 2013. Cakrawala Pendidikan, 1(1), $13-26$.

Kementerian Pendidikan Nasional. (2008). Peraturan Menteri Pendidikan Nasional Republik Indonesia Nomor 2 Tahun 2008.

Kuebler, S., \& Zinsmeister, H. (2014). Corpus Linguistics and Linguistically Annotated Corpora: Bloomsbury Publishing.

Lapp, Diane, Flood, James, \& Farnan, Nancy. (2004). Content Area Reading and Learning: Instructional Strategies. Mahwah: Lawrence Erlbaum.

Listianingsih, Lusiana, \& Harjanto, Ignatius. (2013). Language Readability Levels of Reading Passages and Comprehension Levels of Exercises in Scaffolding English Coursebooks. Anima, Indonesian Psychological Journal 28(3), 154-162.

Manzo, Anthony V., \& Manzo, Ula Casale. (1990). Content Area Reading : a Heuristic Approach. Columbus: Merrill Pub. Co.

McAlpine, Rachel. (2005). Global English for Global Business. Wellington: CC Press.

McCarty, T.L., Watahomigie, L.J., Dien, T., Perez, B., \& Torres-Guzman, M.E. (2004). Sociocultural Contexts of Language and Literacy: Taylor \& Francis.

Meade, Cathy D, \& Smith, Cyrus F. (1991). Readability Formulas: Cautions and Criteria. Patient Education and Counseling, 17(2), 153-158.

Mesmer, Heidi Anne E. (2008). Tools for Matching Readers to Texts : ResearchBased Practices. New York: Guilford Press.

Nuttall, Christine. (2005). Teaching Reading Skills in A Foreign Language (3rd ed.). Oxford: Macmillan.

Olson, Mary W., \& Dishner, Ernest K. (2004). Content Area Reading: Historical Perspective. In D. Lapp, J. Flood \& N. Farnan (Eds.), Content Area Reading and Learning: Instructional Strategies (pp. 3-14). Mahwah: Lawrence Erlbaum.

Rahmawati, Yuly Ika, \& Lestari, Hj Lies Amin. (2014). The Readability Level of Reading Texts in The English Language Textbooks Used By The Tenth Grade. RETAIN, 2(3).

Richards, Jack C. (2001). Curriculum Development in Language Teaching. Cambridge: Cambridge University Press. 
Richards, Jack C., \& Schmidt, Richard W. (2010). Longman Dictionary of Language Teaching and Applied Linguistics (4th ed.). Harlow: Longman.

Schmidt, Renita Revland, \& Thomas, Paul Lee. (2009). 21st Century Literacy: If We are Scripted, are We Literate? (Vol. 5). London: Springer Science \& Business Media.

Steffensen, Margaret S., Joag-Dev, Chitra, \& Anderson, Richard C. (1979). A Cross-Cultural Perspective on Reading Comprehension. Reading Research Quarterly, 10-29.

Sukmadinata, Nana Syaodih. (2007). Kurikulum dan Pembelajaran. In FIP-UPI (Ed.), Ilmu dan Aplikasi Pendidikan Bagian 2 (pp. 97-132). Bandung: PT Imtima Grasindo.

Wijaya, M Sayid. (2015). Readability of Reading Texts in Alexander's Practice and Progress: An Integrated Course for Pre Intermediate Students. Jurnal English Education, 5(1), 100-113.

Zamanian, Mostafa, \& Heydari, Pooneh. (2012). Readability of Texts: State of the Art. Theory and Practice in Language Studies, 2(1), 43-53. 